\title{
OPEN Synthesis and characterization of $\mathrm{Mg}-\mathrm{Zn}$ ferrite based flexible microwave composites and its application as SNG metamaterial
}

\author{
Md Atiqur Rahman ${ }^{1 凶}$, Mohammad Tariqul Islam ${ }^{1 凶}$, Mandeep Singh Jit Singh $^{1}$, \\ Md Samsuzzaman ${ }^{2}$ \& Muhammad E. H. Chowdhury
}

In this article, we propose SNG (single negative) metamaterial fabricated on Mg-Zn ferrite-based flexible microwave composites. Firstly, the flexible composites are synthesized by the sol-gel method having four different molecular compositions of $\mathbf{M g}_{\mathrm{x}} \mathrm{Zn}_{(1-\mathrm{x})} \mathrm{Fe}_{2} \mathrm{O}_{4}$, which are denoted as $\mathbf{M g}_{20}, \mathbf{M g}_{40}$, $\mathrm{Mg}_{60}$, and $\mathrm{Mg}_{80}$. The structural, morphological, and microwave properties of the synthesized flexible composites are analyzed using X-ray diffraction (XRD), field emission scanning electron microscopy (FESEM), and conventional dielectric assessment kit (DAK) to justify their possible application as dielectric substrate at microwave frequency regime. Thus the average grain size is found from 20 to $24 \mathrm{~nm}$, and the dielectric constants are 6.01, 5.10, 4.19, and 3.28, as well as loss tangents, are 0.002 , $\mathbf{0 . 0 0 4}, \mathbf{0 . 0 0 6}$, and 0.008 for the prepared $\mathrm{Mg}-\mathrm{Zn}$ ferrites, i.e., $\mathrm{Mg}_{20}, \mathrm{Mg}_{40}, \mathrm{Mg}_{60}$, and $\mathrm{Mg}_{80}$ respectively. Besides, the prepared low-cost Mg-Zn ferrite composites exhibit high flexibility and lightweight, which makes them a potential candidate as a metamaterial substrate. Furthermore, a single negative (SNG) metamaterial unit cell is fabricated on the prepared, flexible microwave composites, and their essential electromagnetic behaviors are observed. Very good effective medium ratios (EMR) vales are obtained from 14.65 to 18.47 , which ensure the compactness of the fabricated prototypes with a physical dimension of $8 \times 6.5 \mathrm{~mm}^{2}$. Also, the proposed materials have shown better performances comparing with conventional FR4 and RO4533 materials, and they have covered S-, C-, X-, Ku-, and $\mathrm{K}$-band of microwave frequency region. Thus, the prepared, flexible SNG metamaterials on $\mathrm{Mg}_{\mathrm{x}} \mathrm{Zn}_{(1-\mathrm{x})} \mathrm{Fe}_{2} \mathrm{O}_{4}$ composites are suitable for microwave and flexible technologies.

In present-day innovation, oxide-based flexible microwave composites are pulling in enormous significance in light of their exceptional physical properties and likely applications in the territory of microwave and nanotechnology ${ }^{1,2}$. Due to having high electrical resistivity and nano-scaled size alongside selective physical and substance structures, among others, the metal ferrites in their two structures; spinel ferrite (as mild) and hexaferrite (as hard) is a conspicuous applicant as electromagnetic materials ${ }^{3}$. In spinel structure, ferrites, having high chemical and thermal dependability, offer multifunctional materials applied in different fields, for example, biomedicine, catalysis, magnetic recording, and detecting ${ }^{4,5}$. Metal-based composites have drawn more attention than other composites. A portion of these materials containing $\mathrm{Mg}$, $\mathrm{Zn}, \mathrm{Fe}, \mathrm{Ag}$, or Co particles arbitrarily disseminated in porous ferrite host was synthesized to acquire negative electromagnetic parameters in the radio frequency range $^{6-8}$, and they also been broadly used in quite a lot of applications like energy harvesting ${ }^{9}$, space application $^{10,11}$, filter design ${ }^{12}$, antenna design ${ }^{13}$, electromagnetic absorber ${ }^{14-16}$, etc. Moreover, the development of flexible composite is a highly demandable field in the microwave communication system due to having superior properties, low fabrication cost, ease of synthesis. They include various organic and inorganic materials, liquid metals, polydimethylsiloxane, and liquid crystal polymers ${ }^{17-20}$. To achieve such flexible ferrite composites, researchers have developed different types of metal ferrites such as $\mathrm{MgFe}_{2} \mathrm{O}_{4}, \mathrm{CoFe}_{2} \mathrm{O}_{4}, \mathrm{ZnFe}_{2} \mathrm{O}_{4}, \mathrm{Mg}_{\mathrm{x}} \mathrm{Zn}_{(1-\mathrm{x})} \mathrm{Fe}_{2} \mathrm{O}_{4}$

\footnotetext{
${ }^{1}$ Department of Electrical, Electronic and Systems Engineering, Faculty of Engineering and Built Environment, Universiti Kebangsaan Malaysia, 43600 Bangi, Selangor, Malaysia. ${ }^{2}$ Department of Computer and Communication Engineering, Faculty of Computer Science and Engineering, Patuakhali Science and Technology University, Dhaka, Bangladesh. ${ }^{3}$ Department of Electrical Engineering, Qatar University, 2713, Doha, Qatar. ${ }^{\square}$ email: p102555@ siswa.ukm.edu.my; tariqul@ukm.edu.my; mchowdhury@qu.edu.qa
} 
for various applications like as flexible sensors, flexible battery, flexible memory, flexible displays, and others which may not possible with rigid materials ${ }^{21-25}$.

Among the metal ferrites, Magnesium Zinc Ferrite $\left(\mathrm{MgZnFe}_{2} \mathrm{O}_{4}\right)$ is nothing but a combination of iron oxide $\left(\mathrm{Fe}_{2} \mathrm{O}_{3}\right)$ and $\mathrm{Mg}-\mathrm{Zn}$ metal with typical spinel assemblage. The universal formulary $\mathrm{A}_{\mathrm{x}} \mathrm{B}_{(1-\mathrm{x})} \mathrm{Fe}_{2} \mathrm{O}_{4}$, where "A" and " $\mathrm{B}$ " both are divalent transition ions. The $\mathrm{MgZnFe}_{2} \mathrm{O}_{4}$ is fundamentally a dual oxide arrangement $\left(\mathrm{MgO}-\mathrm{ZnO}-\mathrm{Fe}_{2} \mathrm{O}_{2}\right)$ that has maybe applicable as absorbents, semiconductors, and catalysts ${ }^{26}$. In original form, and $\mathrm{Fe}_{2} \mathrm{O}_{4}$ is a dielectric insulator, and $\mathrm{MgO}$ and $\mathrm{ZnO}$ are p-type semiconductors. The $\mathrm{MgZnFe}_{2} \mathrm{O}_{4}$ is the combined form of the $\mathrm{MgO}, \mathrm{ZnO}$, and $\mathrm{Fe}_{2} \mathrm{O}_{4}$, and it offers few extraordinary electrical characteristics that do not exist at their discrete elements ${ }^{27,28}$. The dielectric and physical properties of $\mathrm{MgZnFe}_{2} \mathrm{O}_{4}$ are strongly influenced by the synthesis methods. From the time being, different methods were used by the researchers to synthesis crystalline $\mathrm{MgZnFe}_{2} \mathrm{O}_{4}$ like hydrothermal ${ }^{29}$, solid-state reaction ${ }^{30}$, mechano-chemical synthesis ${ }^{31}$, and sol-gel ${ }^{32-35}$. However, it has not been discovered much for microwave applications such as dielectric substrate materials for microwave antenna or metamaterials. The materials in nature are made of atoms or molecules, while the metamaterial is engineered with artificially ordered repetitive structures; each structure is known as a unit cell, like an atom of materials ${ }^{36-38}$. The property of a metamaterial depends on the structure of the unit cell, equivalent to the atom or molecule of natural materials. The performance of metamaterial could vary upon the modification of those unit cells ${ }^{39,40}$. In contrast, metamaterial may be designed to manipulate numerous properties (such as negative dielectric permittivity, negative magnetic permeability, refractive index close to zero, negative refractive index) of those applications influenced by the electromagnetic wave that cannot be found in nature ${ }^{41-44}$. The tunable negative permeability and permittivity of meta-composites can be accomplished by modifying their microstructures and compositions ${ }^{45-49}$. Typically, the metamaterials are designed on solid substrates fabricated on FR-4, Rogers, silicon, Teflon, and Taconic materials.

Thus, in this work, we at first attempted to synthesize and characterize flexible microwave composites based on $\mathrm{Mg}-\mathrm{Zn}$ ferrite $\left[\mathrm{Mg}_{\mathrm{x}} \mathrm{Zn}_{(1-\mathrm{x})} \mathrm{Fe}_{2} \mathrm{O}_{4}\right]$ with four different concentrations of $\mathrm{Mg}$ to form SNG metamaterial.

The flexible microwave substrates are prepared using the sol-gel method to form flexible metamaterials. The sol-gel method offers numerous advantages like good stoichiometric control, high homogeneity, high productivity at low temperatures, and also able to produce unalloyed ultrafine powders. The advantages of the prepared composites are they are cost-effective, highly flexible, lightweight, and applicable incase of wearable devices. Field emission scanning electron microscopy (FESEM), X-ray diffraction (XRD), and dielectric assessment kit (DAK) was utilized to investigate the surface morphology, crystalline structures, and microwave properties of the developed $\mathrm{Mg}-\mathrm{Zn}$ ferrite based flexible composites. Furthermore, metamaterial structures were fabricated on all these composites, which performed as the flexible substrates, and their transmission $\left(\mathrm{S}_{21}\right)$ coefficients and effective parameters were analyzed using the commercially available CST Microwave Studio and MATLAB. Also, the proposed materials are compared with conventional FR4 and RO4533 materials, and better performances were observed by the proposed composites. At last, very good EMR values are found in all cases with and it is observed that the designed metamaterial on flexible $\mathrm{Mg}_{\mathrm{x}} \mathrm{Zn}_{(1-\mathrm{x})} \mathrm{Fe}_{2} \mathrm{O}_{4}$ composites can meet all the expectations for S-, C-, X-, Ku-, and K-band applications and in the field of flexible microwave technologies.

\section{Experimentals}

Preparation of $\mathrm{Mg}-\mathrm{Zn}$ Ferrite based flexible composites. The overall synthesis steps of $\mathrm{Mg}-\mathrm{Zn}$ ferrite $\left[\mathrm{Mg}_{\mathrm{x}} \mathrm{Zn}_{(1-\mathrm{x})} \mathrm{Fe}_{2} \mathrm{O}_{4}\right]$ based flexible composites through the sol-gel method are illustrated in Fig. 1 with a flow chart. Magnesium nitrate hexahydrate $\left[\mathrm{Mg}\left(\mathrm{NO}_{3}\right)_{2} \cdot 6 \mathrm{H}_{2} \mathrm{O}\right]$, zinc nitrate $\left[\mathrm{Zn}_{2}\left(\mathrm{NO}_{3}\right)_{2} \cdot 6 \mathrm{H}_{2} \mathrm{O}\right]$, and ferric nitrate $\left[\mathrm{Fe}\left(\mathrm{NO}_{3}\right)_{3} \cdot 9 \mathrm{H}_{2} \mathrm{O}\right]$ are taken as primary substances. To characterize the compositional effect of $\mathrm{Mg}$ and $\mathrm{Zn}$ content on ferrites, there are four different molar ratios taken such as $20 \%, 40 \%, 60 \%$, and $80 \%$ of $\mathrm{Mg}$ nitrate and labeled as $\mathrm{Mg}_{20}, \mathrm{Mg}_{40}, \mathrm{Mg}_{60}$, and $\mathrm{Mg}_{80}$. (1) For $\mathrm{Mg}_{20}, 20 \%$ of $\mathrm{Mg}$ nitrate and $80 \%$ of $\mathrm{Zn}$ nitrate is used. Similarly, (2) for $\mathrm{Mg}_{40}, 40 \%$ of $\mathrm{Mg}$ nitrate and $60 \%$ of $\mathrm{Zn}$ nitrate is taken as a molar ratio. In this manner, (3) for the $\mathrm{Mg}_{60}$ $60 \%$ of $\mathrm{Mg}$ nitrate and $40 \%$ of $\mathrm{Zn}$ nitrate, and (4) for $\mathrm{Mg}_{80} 80 \%$ of $\mathrm{Mg}$ nitrate and $20 \%$ of $\mathrm{Zn}$ nitrate is weighted as a molar ratio. The mixers are slowly dissolved in distilled water with magnetic stirring, and also the citric acid $\left(\mathrm{C}_{6} \mathrm{H}_{8} \mathrm{O}_{7} \cdot \mathrm{H}_{2} \mathrm{O}\right)$ is added as a chelating agent, and hence, a quite transparent gelatinous solution is found having light red color. Later, the appeared solutions are stirring continuously for about 5 hours at $90^{\circ} \mathrm{C}$. Thus, a reddish gel is formed, which is further dried at $150^{\circ} \mathrm{C}$ by transferring the gel into a furnace. The nanoparticle was then achieved by grinding the obtained precursor and, finally, calcined at $750{ }^{\circ} \mathrm{C}$ for one hour to complete the chemical process.

Figure 2 shows the main preparation steps of the flexible substrate-based metamaterials from their gel states to fabricated metamaterial unit cells. Firstly, the flexible substrate is prepared by adding the synthesized $\mathrm{MgZnFe}_{2} \mathrm{O}_{4}$ nanoparticle into the PVA glue at a ratio of $1 \mathrm{~g}$ powder to $10 \mathrm{~mL}$ of PVA glue and later dried at $80^{\circ} \mathrm{C}$. Finally, the metamaterial unit cell is fabricated upon these $\mathrm{Mg}_{20}, \mathrm{Mg}_{40}, \mathrm{Mg}_{60}$, and $\mathrm{Mg}_{80}$ flexible substrates by copper sputtering.

Fabrication of metamaterial on $\mathrm{Mg}-\mathrm{Zn}$ ferrite based flexible composites. In this design, four different types of flexible substrates are used, termed $\mathrm{Mg}_{20}, \mathrm{Mg}_{40}, \mathrm{Mg}_{60}$, and $\mathrm{Mg}_{80}$, based on magnesium zinc ferrites $\left(\mathrm{MgZnFe}_{2} \mathrm{O}_{4}\right)$. Figure 3a represents the geometrical view of the proposed unit cell. During CST simulation frequency-domain solver is used. The electromagnetic wave propagates from the positive $\mathrm{z}$-axis to the negative $\mathrm{z}$-axis, which is energized by two waveguide ports as the simulation setup is shown in Fig. 3b. The $\mathrm{x}$ and $\mathrm{y}$ boundaries are set as perfect electric (PEC) and perfect magnetic (PMC) walls. The necessary design parameters, along with their dimensions, are shown in Table 1 . The substrate length is chosen $8 \mathrm{~mm}$, and width $b$ is chosen $6.5 \mathrm{~mm}$, where the thickness of the substrate is $0.5 \mathrm{~mm}$ for all cases. The unit cell is fabricated on flexible substrates using copper sputtering with a thickness of $0.035 \mathrm{~mm}$. Here, $L 1$ and $W 1$ are the length and width of the outer split ring resonator with a dimension of $5.25 \mathrm{~mm}$ and $7.5 \mathrm{~mm}$, respectively. On the other hand, $L 2$ and $W 2$ are the length 


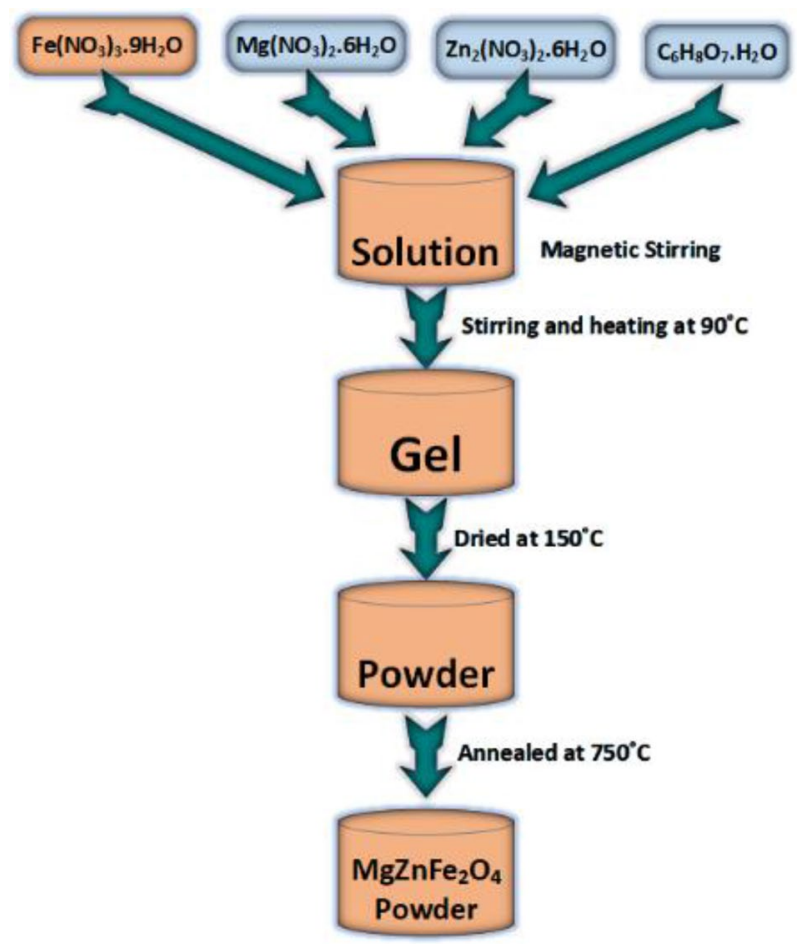

Figure 1. Flowchart of $\mathrm{MgZnFe}_{2} \mathrm{O}_{4}$ nanoparticle preparation.

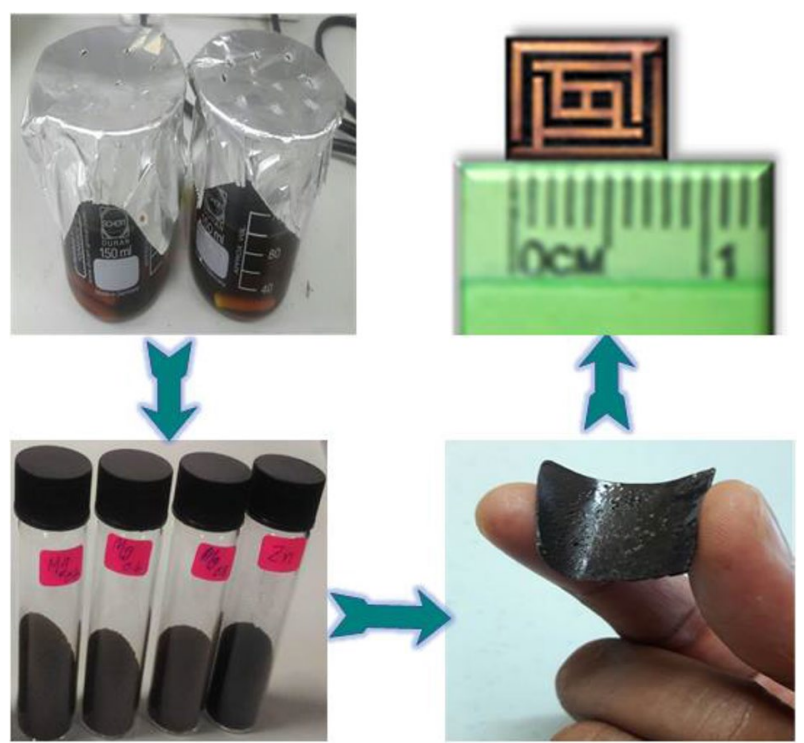

Figure 2. Flowchart of $\mathrm{MgZnFe}_{2} \mathrm{O}_{4}$ nanoparticle-based flexible metamaterial cell.

and width of the intermediate split ring resonator with a dimension of $4 \mathrm{~mm}$ and $5 \mathrm{~mm}$, respectively. Moreover, $L 3$ and $W 3$ are the length and width of the inner split ring resonator with a dimension of $3 \mathrm{~mm}$. A $0.25 \mathrm{~mm}$ gap is maintained among the edges of the substrate and the outer resonators, as well as $0.5 \mathrm{~mm}$ of gap $g$ among the inner, middle, and outer resonators from all ends. The width of the copper strips $d$ is also chosen $0.5 \mathrm{~mm}$ for conductive elements. Finally, a $0.25 \mathrm{~mm}$ gap $s$ is maintained for all the splits.

\section{Results and discussion}

Structure. The Siemens D500 X-ray diffractometer having a $\mathrm{Cu} \mathrm{Ka}$ anode $(40 \mathrm{kV}, 20 \mathrm{~mA})$ with a $2 \theta$ angle range of $20^{\circ}$ to $80^{\circ}$ is used to confirm the phase formation of $\mathrm{MgZnFe}_{2} \mathrm{O}_{4}$, and the recorded XRD plot for the synthesized samples are shown in Fig. 4. 


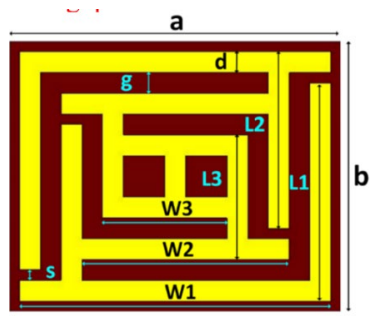

(a)

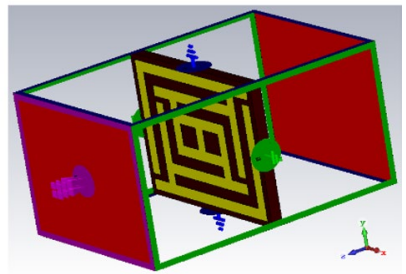

(b)

Figure 3. (a) The geometry and (b) the boundary setup of the metamaterial unit cell.

\begin{tabular}{|c|c|c|c|}
\hline \multirow[b]{2}{*}{ Design parameter } & \multirow{2}{*}{\begin{tabular}{|l|} 
Dimension \\
$\mathrm{mm}$
\end{tabular}} & \multirow[b]{2}{*}{ Design parameter } & \multirow{2}{*}{$\begin{array}{l}\text { Dimension } \\
\mathrm{mm}\end{array}$} \\
\hline & & & \\
\hline$a$ & \begin{tabular}{|l|}
8.00 \\
\end{tabular} & $W 1$ & 7.50 \\
\hline$b$ & 6.50 & $W 2$ & 5.00 \\
\hline$L 1$ & 5.25 & W3 & 3.00 \\
\hline$L 2$ & 4.00 & $d=g$ & 0.5 \\
\hline$L 3$ & 3.00 & $s$ & 0.25 \\
\hline
\end{tabular}

Table 1. Design parameters of metamaterial unit cells.

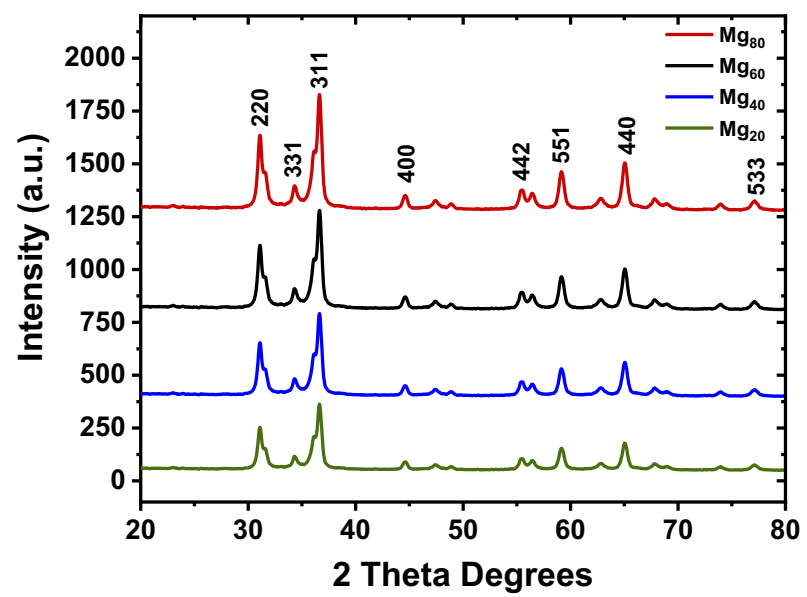

Figure 4. XRD patterns of the prepared $\mathrm{Mg}-\mathrm{Zn}$ ferrites samples.

The spinel structure of $\mathrm{MgZnFe}_{2} \mathrm{O}_{4}$ is identified and indexed with a principal peak of (311) for all $\mathrm{Mg}_{20}, \mathrm{Mg}_{40}$, $\mathrm{Mg}_{60}$, and $\mathrm{Mg}_{80}$, respectively. The overall reflection peaks indexed at $2 \theta=32^{\circ}(220), 35^{\circ}(331), 37^{\circ}(311), 44^{\circ}$ (400), $55^{\circ}(442), 58^{\circ}(551), 65^{\circ}(440), 77^{\circ}(533)$. Scherrer's equation ${ }^{50}$ as follows is used to calculate the average crystallite size of $\mathrm{MgZnFe}_{2} \mathrm{O}_{4}$ from the line width of the (311) reflection.

$$
D=\frac{0.94 \lambda}{\beta \cos \theta}
$$

where $\lambda$ is the wavelength of the $\mathrm{X}$-ray radiation $(1.54060 \mathrm{~nm})$, and $\beta$ is the full width at half maxima values in radians, and $\theta$ is the diffraction angle corresponding to the most intense reflection plane (311). The crystallite sizes of $\mathrm{MgZnFe}_{2} \mathrm{O}_{4}$ nano spinel that evaluated from the above equation (5) are $27.45 \mathrm{~nm}$ for $\mathrm{Mg}_{20}, 25.75 \mathrm{~nm}$ for $\mathrm{Mg}_{40}, 23.84 \mathrm{~nm}$ for $\mathrm{Mg}_{60}, 22.17 \mathrm{~nm}$ for $\mathrm{Mg}_{80}$, which is very close to the tabulated values reported by $\mathrm{S}$. B. Somvanshi et al. ${ }^{51}$. The lattice constraint $(a)$ was calculated with the help of Miller indices $(h k l)$ information and interplanar spacing $(d)$ values corresponding to leading peak (311) by the following equation:

$$
a=d \sqrt{h^{2}+k^{2}+l^{2}}
$$

The evaluated values of the lattice constraint of $\mathrm{MgZnFe}_{2} \mathrm{O}_{4}$ are $a=8.433 \AA$ for $\mathrm{Mg}_{20}, a=8.425 \AA$ for $\mathrm{Mg}_{40}$, $a=8.415 \AA$ for $\mathrm{Mg}_{60}$, and $a=8.405 \AA$ for $\mathrm{Mg}_{80}$, which also very similar to that presented $\mathrm{in}^{51}$. The calculated values 


\begin{tabular}{|l|l|l|l|l|l|l|}
\hline Mg concentration (\%) & $\boldsymbol{a}(\boldsymbol{\AA})$ & $\boldsymbol{V}\left(\AA^{3}\right)$ & $\boldsymbol{D}(\mathbf{n m})$ & $\boldsymbol{d}_{\boldsymbol{x}}\left(\mathbf{g m} / \mathbf{c m}^{3}\right)$ & $\boldsymbol{d}_{\boldsymbol{B}}\left(\mathbf{g m} / \mathbf{c m}^{3}\right)$ & $\boldsymbol{P}(\%)$ \\
\hline 20 & 8.433 & 599.72 & 27.45 & 5.306 & 3.627 & 31.64 \\
\hline 40 & 8.425 & 598.01 & 25.75 & 5.103 & 3.577 & 29.91 \\
\hline 60 & 8.415 & 595.88 & 23.84 & 4.925 & 3.513 & 28.66 \\
\hline 80 & 8.405 & 593.76 & 22.17 & 4.747 & 3.412 & 28.13 \\
\hline
\end{tabular}

Table 2. Values of Lattice parameter $(a)$, Unit cell volume $(V)$, Average crystallite size $(D)$, X-ray density $\left(d_{x}\right)$, Bulk density $\left(d_{B}\right)$, Porosity $(P)$ for prepared $\mathrm{Mg}_{\mathrm{x}} \mathrm{Zn}_{(1-\mathrm{x})} \mathrm{Fe}_{2} \mathrm{O}_{4}$ samples.

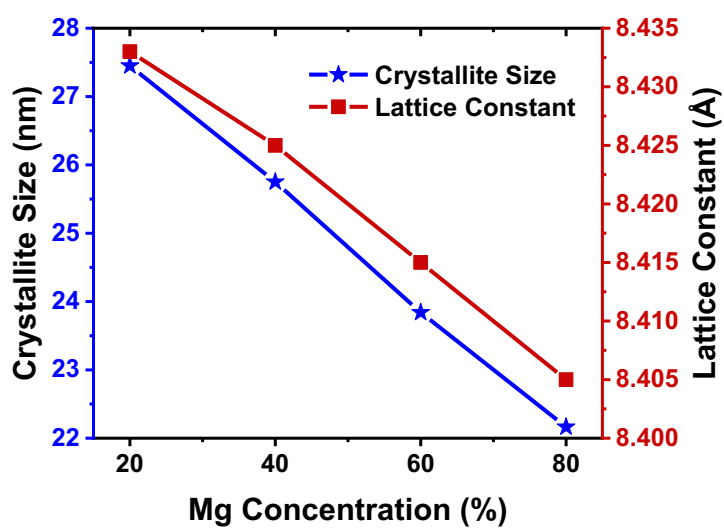

(a)

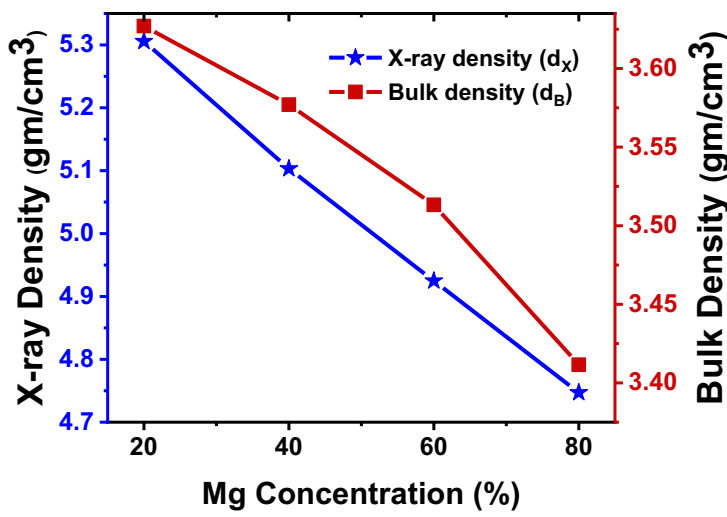

(b)

Figure 5. Variation (a) crystallite size and lattice constant and (b) X-ray density and bulk density of the prepared $\mathrm{MgZnFe}_{2} \mathrm{O}_{4}$ samples with different $\mathrm{Mg}$ concentrations.

of lattice constant $(a)$ and average crystallite size $(D)$ are accommodated in Table 2 , and the compositional variation of lattice constant and average crystallite size concerning $\mathrm{Mg}^{2+}$ substitution is shown in Fig. $5 \mathrm{a}$.

From Fig. 5a, it is seen that due to the increasing percentages of $\mathrm{Mg}^{2+}$ content $\mathrm{x}$, the values of the lattice constant $(a)$ and crystalline size are decreasing. This scenario has happened by following Vegard's law ${ }^{52}$. Also, these decreasing characteristics can be validated based on theistinction of the ionic length of magnesium and zinc ions.

The volume $(V)$ of the unit cell of the synthesized samples can be computed with the help of lattice constant (a) by the following formula:

$$
V=a^{3}
$$

As the unit cell volume values are directly proportional to the lattice parameter values, thus it shows the same trend as the values of the lattice constant. Hence, the X-ray density factor calculation is necessary to characterize materials. Therefore, the values of the X-ray density $\left(d_{X}\right)$ can be determined from the following equation:

$$
d_{X}=\frac{Z \times M}{V \times N_{A}}
$$

where $Z$ represents the cubic lattice coordination number, $M$ represents the molecular weight of individual concentrations, $V$ is the volume of the unit cell, and $N_{A}$ is the Avogadro's number (i.e., $N_{A}=6.022 \times 10^{23}$ ). Figure $5 \mathrm{~b}$ represents the X-ray density $\left(d_{x}\right)$ and the bulk density $\left(d_{B}\right)$ variation with various compositions. It is investigated that the values of the X-ray density $\left(d_{x}\right)$ and the bulk density $\left(d_{B}\right)$ are decreases with an increase of $\mathrm{Mg}^{2+}$ ions. It may happen due to the molecular weight loss of the synthesized samples. Finally, from the values of the X-ray density $\left(d_{x}\right)$ and the bulk density $\left(d_{B}\right)$, the percentage of porosity $(P)$ is calculated by the equation below:

$$
P=1-\frac{d_{B}}{d_{X}}
$$

The calculated values of the X-ray density $\left(d_{x}\right)$ and the bulk density $\left(d_{B}\right)$, and the percentage of porosity $(P)$ are also summarized in Table 2.

Morphology. The FESEM (Field Emission Scanning Electron Microscopy) technique is used to investigate the morphology of the synthesized nanoparticle. Figures 6 and 7 represents the FESEM images and particle size histograms of $\mathrm{Mg}_{20}, \mathrm{Mg}_{40}, \mathrm{Mg}_{60}$, and $\mathrm{Mg}_{80}$. A high-energy ball mill EMAX (Retsch, Germany) was utilized for grinding the $\mathrm{Mg}_{\mathrm{x}} \mathrm{Zn}_{(1-\mathrm{x})} \mathrm{Fe}_{2} \mathrm{O}_{4}$ species to nanocrystals which allows faster grinding with a maximum revolutionary speed of $2000 \mathrm{rpm}$ and produce unique size particles. Zirconium oxide grinding balls having $0.5 \mathrm{~mm}$ size were used to grind the materials for about 3 hours. The mean grain size of the synthesized nanoparticle is 




(a)

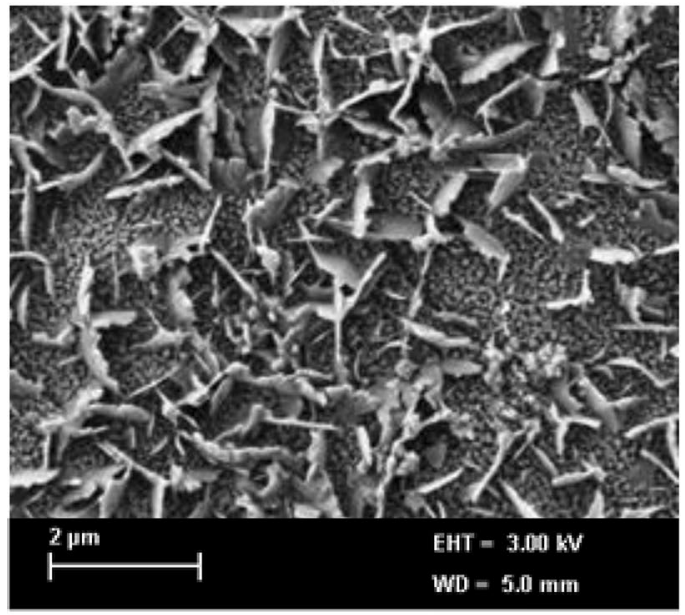

(c)



(b)

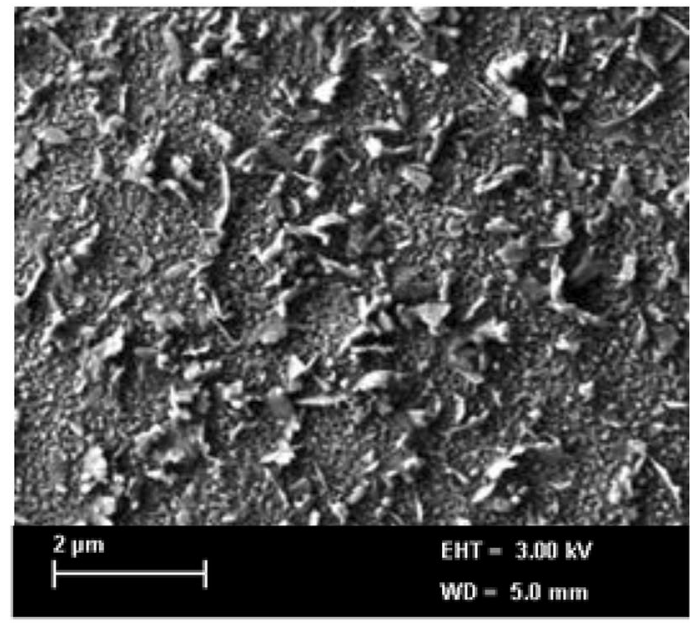

(d)

Figure 6. FSEM images of $\mathrm{Mg}-\mathrm{Zn}$ ferrite nano powder (a) $\mathrm{Mg}_{20}$, (b) $\mathrm{Mg}_{40}$, (c) $\mathrm{Mg}_{60}$, and (d) $\mathrm{Mg}_{80}$ respectively.

approximately $27.30 \mathrm{~nm}$ for $\mathrm{Mg}_{20}, 25.60 \mathrm{~nm}$ for $\mathrm{Mg}_{40}, 23.70 \mathrm{~nm}$ for $\mathrm{Mg}_{60}$, and $22.02 \mathrm{~nm}$ for $\mathrm{Mg}_{80}$, which have a good agreement with the values obtained from XRD analysis. It is also observed that with increases in $\mathrm{Mg}$ content, the grain size and porosity are decreased, which also significantly affects on dielectric properties of the materials and leads to having tunable properties.

Optical and photoluminescence analysis. The optical energy bandgap $\left(\mathrm{E}_{\mathrm{g}}\right)$ of the prepared samples is determined using the UV-Vis spectrophotometer. The wavelength of the applied light is chosen from $300 \mathrm{~nm}$ to 800 $\mathrm{nm}$. For evaluating the optical energy bandgap $\left(\mathrm{E}_{\mathrm{g}}\right)$ values, the most popular "Tauc plot" $\left[(\mathrm{ahv})^{2} \mathrm{v} / \mathrm{s}\left(\mathrm{E}_{\mathrm{g}}\right)\right]$ was drawn from the UV-Vis absorbance spectral data. The "Tauc plot" was drawn using the following relation, and the plots are displayed in Fig. 8a.

$$
\alpha=\frac{A\left(h v-E_{g}\right)^{n / 2}}{h v}
$$

The optical bandgap energy $\left(\mathrm{E}_{\mathrm{g}}\right)$ parameters were determined from the tangent drawn at the X-axis of the "Tauc plots," as shown in Fig. 8a. The values of ' $E_{g}^{\prime}$ 'were found to be in the range of $2.20-2.36 \mathrm{eV}$. The photoluminescent properties were studied for the prepared samples by the photoluminescence (PL) spectra excited at a wavelength of $400 \mathrm{~nm}$. Fig. $8 \mathrm{~b}$ demonstrates the PL spectra recorded at $300 \mathrm{~K}$. The distinctive near band-edge emission (NBE) for all the samples was observed at the wavelength range of 524-530 nm. These variations in optical energy bandgap $\left(\mathrm{E}_{\mathrm{g}}\right)$ and PL spectra is happened due to variations of material concentration as well as grain size, cation distribution, etc.

Magnetic analysis. The $\mathrm{M}-\mathrm{H}$ hysteresis loops from the prepared $\mathrm{Mg}-\mathrm{Zn}$ ferrite samples are presented in Fig $9 \mathrm{a}$, where $\mathrm{M}$ and $\mathrm{H}$ stand for the magnetization and magnetic field values, respectively. The $\mathrm{M}-\mathrm{H}$ hysteresis data are collected by a SQUID-VSM magnetometer at room temperature, and very narrow loops are observed having almost no hysteresis behavior. Thus, the prepared $\mathrm{Mg}-\mathrm{Zn}$ ferrite samples exhibit the properties like soft mag- 


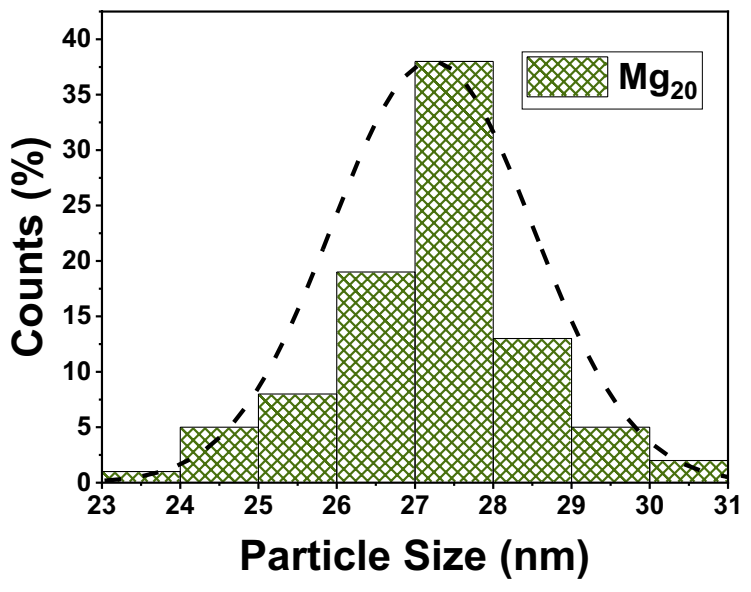

(a)

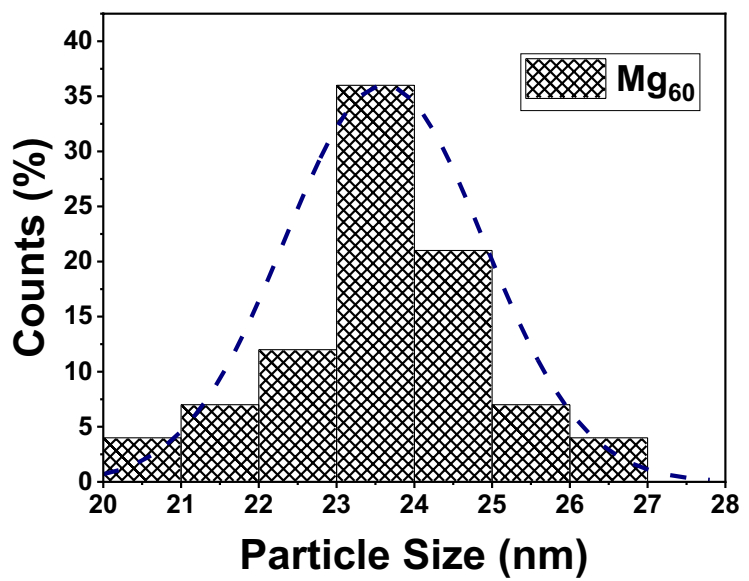

(c)

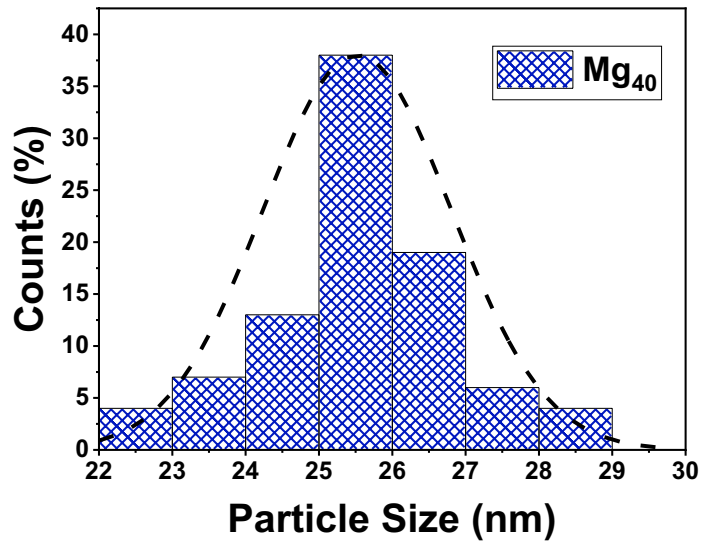

(b)

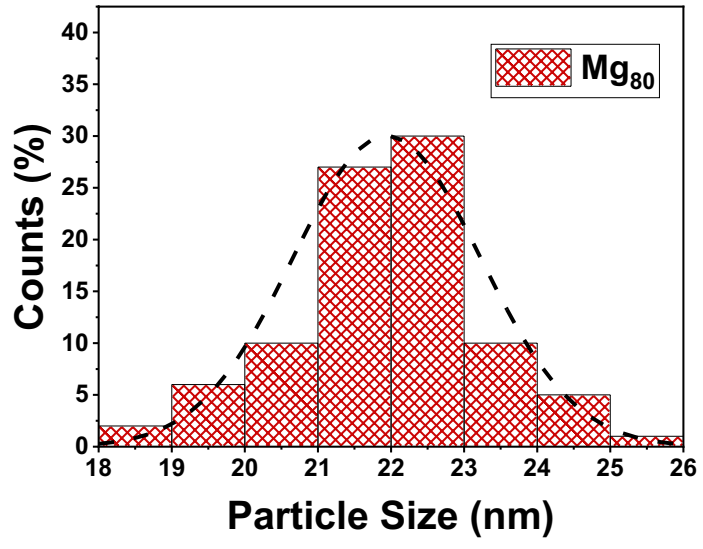

(d)

Figure 7. Particle size histogram of $\mathrm{Mg}-\mathrm{Zn}$ ferrite nanopowder (a) $\mathrm{Mg}_{20}$, (b) $\mathrm{Mg}_{40}$, (c) $\mathrm{Mg}_{60}$, and (d) $\mathrm{Mg}_{80}$ respectively.

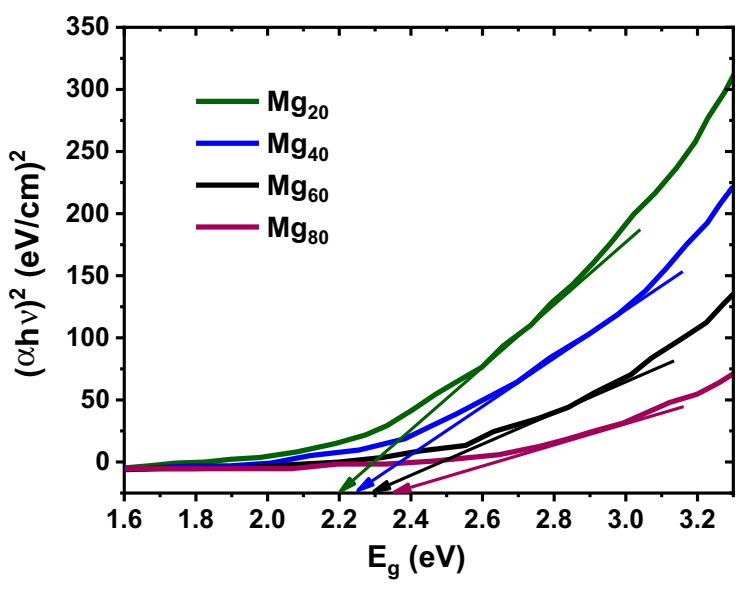

(a)



(b)

Figure 8. (a) Tauc plots and (b) PL spectra of Mg-Zn ferrite samples.

netic material. Figure 9a also shows that the $\mathrm{Mg}_{\mathrm{x}} \mathrm{Zn}_{(1-\mathrm{x})} \mathrm{Fe}_{2} \mathrm{O}_{4}$ nanoparticles' maximum magnetization increased with increases in the $\mathrm{Mg}$ content. It is noted that the magnetic hysteresis loops of the $\mathrm{Mg}-\mathrm{Zn}$ ferrite nanoparticles did not reach complete saturation even when the applied magnetic field was $10 \mathrm{kOe}$. This feature is often found in spinel ferrite nanoparticles. It can be ascribed to the presence of a spin-disordered layer on nanoparticle surfaces, which requires a large magnetic field to saturate together with the concomitant effect of the size of the 


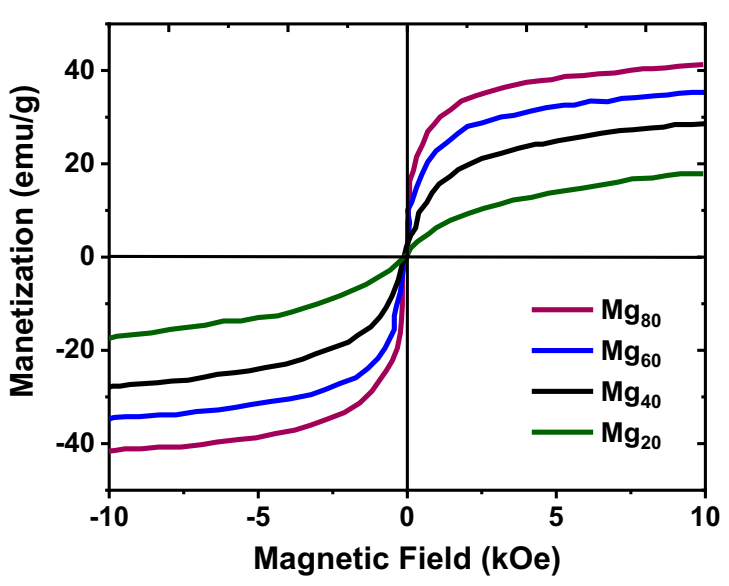

(a)

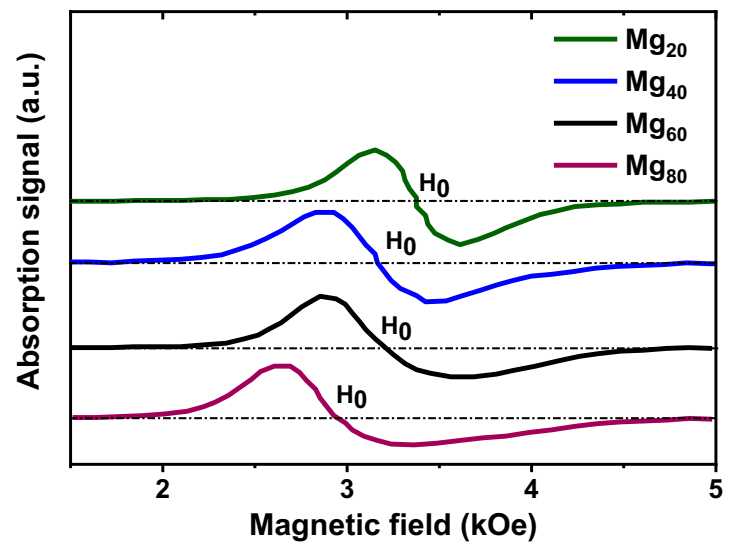

(b)

Figure 9. (a) Comparison of magnetization versus magnetic field (M-H) hysteresis loops and (b) ferromagnetic resonance (FMR) spectra of $\mathrm{Mg}-\mathrm{Zn}$ ferrite samples.

ultrafine ferrite particles. The ferromagnetic resonance (FMR) spectra of four Mg-Zn ferrite nanoparticle samples are plotted in Fig. 9b. The resonance field was found to be between 2.65 and $3.20 \mathrm{kOe}$. The magnetic study revealed that the obtained $\mathrm{Mg}-\mathrm{Zn}$ ferrite nanoparticles have a potential application in the microwave region.

Dielectric properties. The dielectric constants $\left(\varepsilon_{r}\right)$ and loss tangents $(\tan \delta)$ of the prepared, flexible substrates is measured at a frequency range of $4-10 \mathrm{GHz}$ with the DAK $3.5(200 \mathrm{MHz}$ to $20 \mathrm{GHz})$ dielectric assessment kit as shown in Fig. 10a, manufactured by Schmid and Partner AG, Switzerland, and the plot are shown in Fig. 10b and $c$ respectively. With the increase of applied frequency on the specimen under test, the values of the dielectric constants $\left(\varepsilon_{r}\right)$ and loss tangents $(\tan \delta)$ have slightly fluctuated, which is consistent with Koop's phenomenological hypothesis and the Maxwell-Wagner model of interfacial polarization ${ }^{53,54}$. The calculated values of the relative permittivity $\left(\varepsilon_{r}\right)$ is 6.01 for $\mathrm{Mg}_{20}, 5.10$ for $\mathrm{Mg}_{40}, 4.19$ for $\mathrm{Mg}_{60}$ and 3.28 for $\mathrm{Mg}_{80}$, whereas the values of loss tangents $(\tan \delta)$ are 0.002 for $\mathrm{Mg}_{20}, 0.004$ for $\mathrm{Mg}_{40}, 0.006$ for $\mathrm{Mg}_{60}$ and 0.008 for $\mathrm{Mg}_{80}$. The porosity and the value of the dielectric constants decrease from $6.01\left(\mathrm{Mg}_{20}\right)$ to $3.28\left(\mathrm{Mg}_{80}\right)$ with increases of $\mathrm{Mg}$ content, while the value of loss tangents $(\tan \delta)$ is increased with increases of $\mathrm{Mg}$ content. This variation is originating from the grain size variations of synthesized nanoparticles as found in XRD and SEM analysis too. Thus, the dielectric properties of the prepared $\mathrm{MgZnFe}_{2} \mathrm{O}_{4}$ composites can be tuned by tuning the molar ratios, which is very effective where the predefined or arbitrary values of different dielectric properties are required. Finally, as the prepared, flexible substrates based on $\mathrm{MgZnFe}_{2} \mathrm{O}_{4}$ offers low values of the relative permittivity $\left(\boldsymbol{\varepsilon}_{\boldsymbol{r}}<15\right)$ and very low values of loss tangent $(\tan \delta)$, it can be used as microwave dielectric material suitably.

Electromagnetic properties of the fabricated metamaterials. There has been a wide interest in the application of metamaterials in recent years. The materials in nature are made of atoms or molecules, while the metamaterial is engineered with artificially ordered repetitive structures. Those newly designed structures laid above the base material, including but not limited to their shape, arrangement, and geometry, dominate the property of the metamaterial. Those repetitive structures, often called periodic unit cells, are usually assembled at a scale below the wavelength to manipulate the electromagnetic property of the wave. The property of a metamaterial depends on the structure of the unit cell, equivalent to the atom or molecule of natural materials. The performance of metamaterial could vary upon the modification of those unit cells. In contrast, metamaterial may be designed to manipulate numerous properties of those applications influenced by the electromagnetic wave. Here, CST microwave studio is used to finalize the structure of the metamaterial unit cell before prototyping. Finally, the electromagnetic properties of the proposed flexible metamaterial were measured and extracted with the PNA vector network analyzer (Agilent N5227A, $10 \mathrm{MHz}-67 \mathrm{GHz}$ ).

The simulated transmission coefficient $\left(\mathrm{S}_{21}\right)$ for the proposed metamaterial unit cell on all the four flexible substrates, i.e., $\mathrm{Mg}_{20}, \mathrm{Mg}_{40}, \mathrm{Mg}_{60}$, and $\mathrm{Mg}_{80}$, are shown in Fig. 11a, and the corresponding measured transmission coefficient are shown in Fig. 11b. The effective permittivity, permeability, and refractive index extracted by the Nicolson-Ross-Wire method ${ }^{55}$ are presented in Fig. 11c,d, and e, respectively. Based on the Nicolson-Ross-Wire method, the values of the effective permittivity $\left(\varepsilon_{r}\right)$, permeability $\left(\mu_{r}\right)$, and refractive index $\left(n_{r}\right)$ can be calculated by the following equations:

$$
\begin{aligned}
& \varepsilon_{r} \sim \frac{2}{j k_{0} d} \times \frac{\left(1-V_{1}\right)}{\left(1+V_{1}\right)} \\
& \mu_{r} \sim \frac{2}{j k_{0} d} \times \frac{\left(1-V_{2}\right)}{\left(1+V_{2}\right)}
\end{aligned}
$$



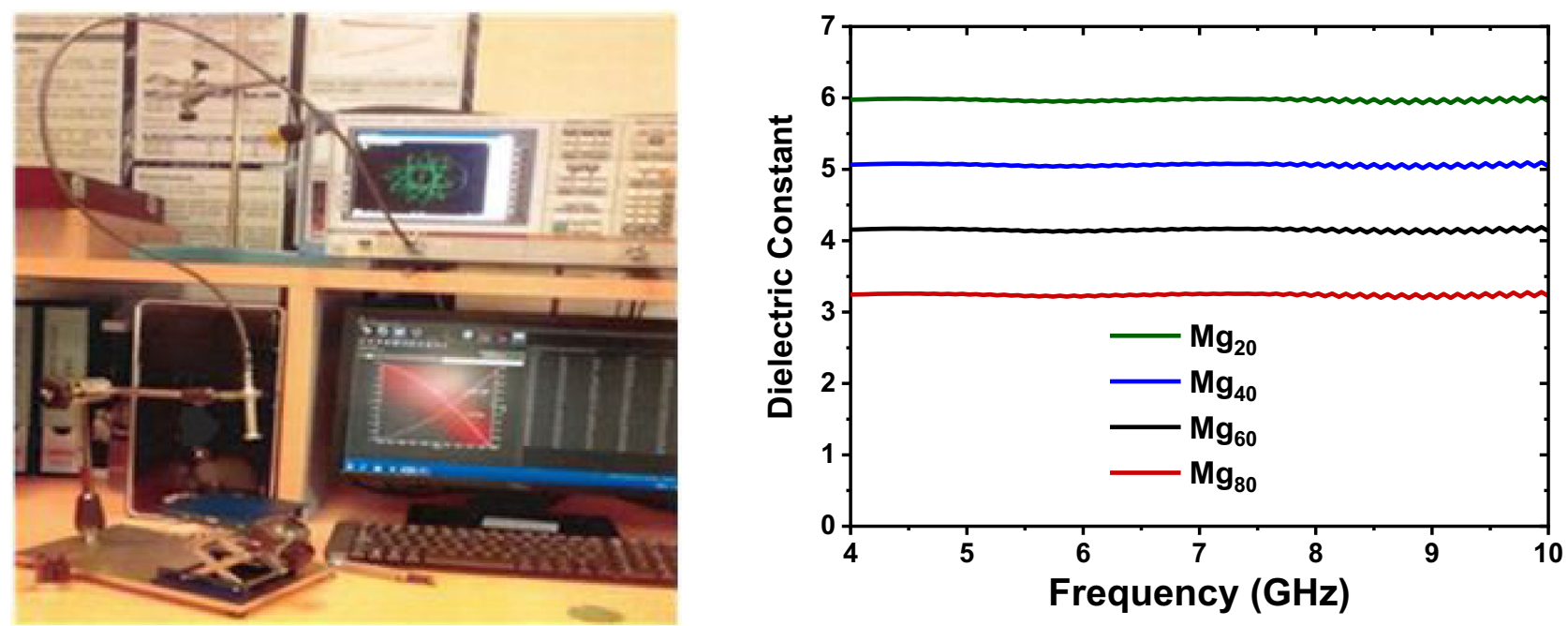

(a)

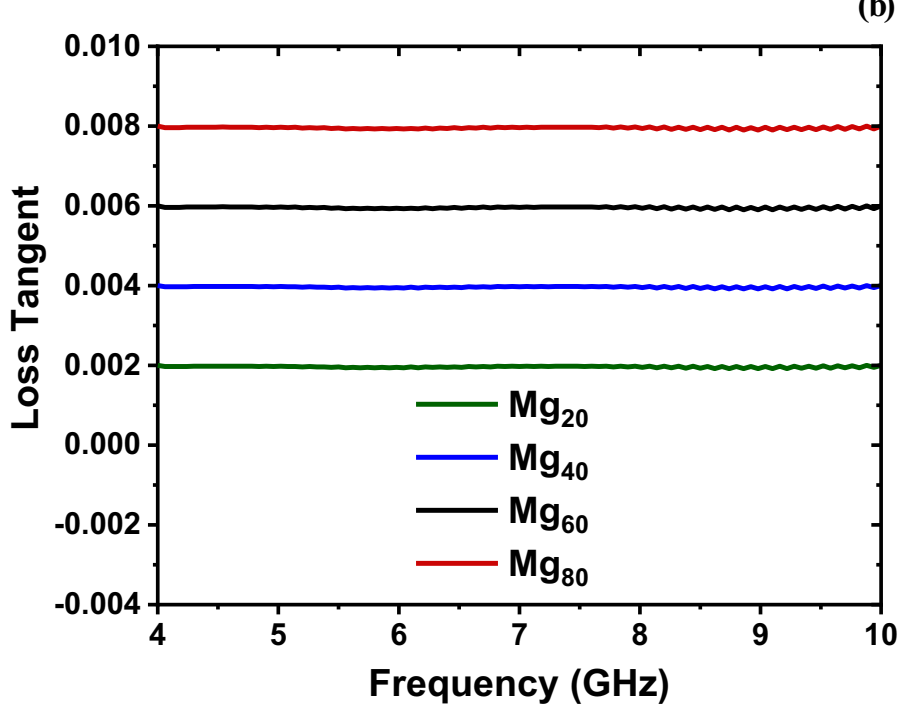

(c)

Figure 10. (a) Dielectric measurement setup with DAK 3.5 kit, (b) Dielectric constant, and (c) Loss tangent $\left(\mathrm{T}_{\delta}\right)$ over frequency.

$$
n_{r}=\sqrt{\mu_{r} \varepsilon_{r}}
$$

where $k_{0}=\frac{2 \pi f}{c}, c$ is the speed of light, and $d$ is the thickness of the substrate. Also, $V_{1}=\left|S_{11}\right|+\left|S_{21}\right|$ and $V_{2}=\left|S_{21}\right|-\left|S_{11}\right|$ in which $S_{11}$ and $S_{21}$ are the reflection and transmission coefficient, respectively.

In the case of $\mathrm{Mg}_{20}$, there are nine simulated resonances observed tabulated in Table 5, whereas there are ten resonances were found during measurement by $\mathrm{Mg}_{20}$. With $\mathrm{Mg}_{40}$, there are seven simulated resonances observed, whereas there are nine resonances were found during measurement by $\mathrm{Mg}_{40}$. For both $\mathrm{Mg}_{60}$ and $\mathrm{Mg}_{80}$, there are seven simulated, and measured resonances were observed, and all of these are tabulated in Table 5. A very good agreement is found among simulated and measured values with a slight frequency shifting. This frequency shifting may happen due to fabrication error and/or external noise during measurements. All the values of effective permeability $\left(\mu_{r}\right)$ were found positive, and the values of effective permittivity $\left(\varepsilon_{r}\right)$ were found negative, corresponding to resonance frequencies. Thus the metamaterial can be declared as single negative (SNG) or epsilon negative (ENG) metamaterial. The negative values of the effective permittivity and refractive index are presented in Table 3. The parameters are quite similar in the pattern for all these four metamaterials but at slightly different frequencies due to having slightly different dielectric properties.

To justify the nobility of proposed flexible substrate materials, the transmission of proposed metamaterials was investigated by replacing the substrate materials with conventional FR4 and Rogers RO4533 materials keeping the unit cell structure remain the same. The obtained transmission coefficient regarding the above cases is shown in Fig. 12. The dielectric constant $\left(\boldsymbol{\varepsilon}_{\boldsymbol{r}}\right)$ values of FR4 and $\mathrm{Mg}_{60}$ are similar but different in loss tangent values. For the same size and structure of the unit cell, there are only five resonances observed with FR4. Besides, with $\mathrm{Mg}_{60}$, there are seven resonances observed and covers more bands of microwave regime. On the other hand, also the dielectric constant $\left(\boldsymbol{\varepsilon}_{r}\right)$ values of $\mathrm{RO} 4533$ and $\mathrm{Mg}_{80}$ are almost similar but different in loss tangent values, and 


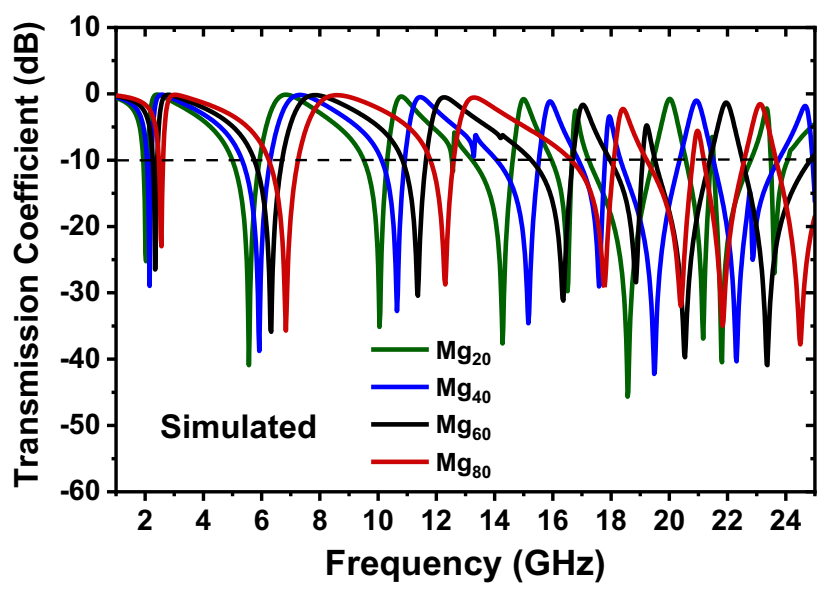

(a)

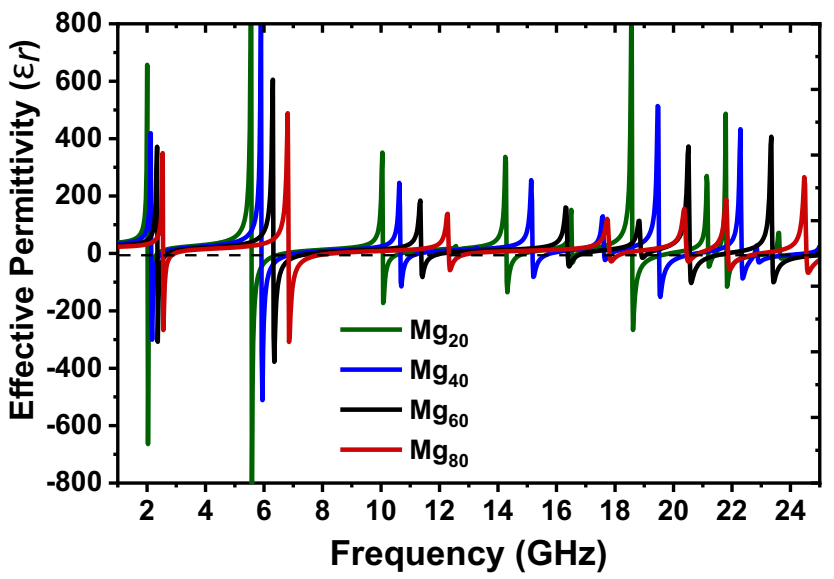

(c)

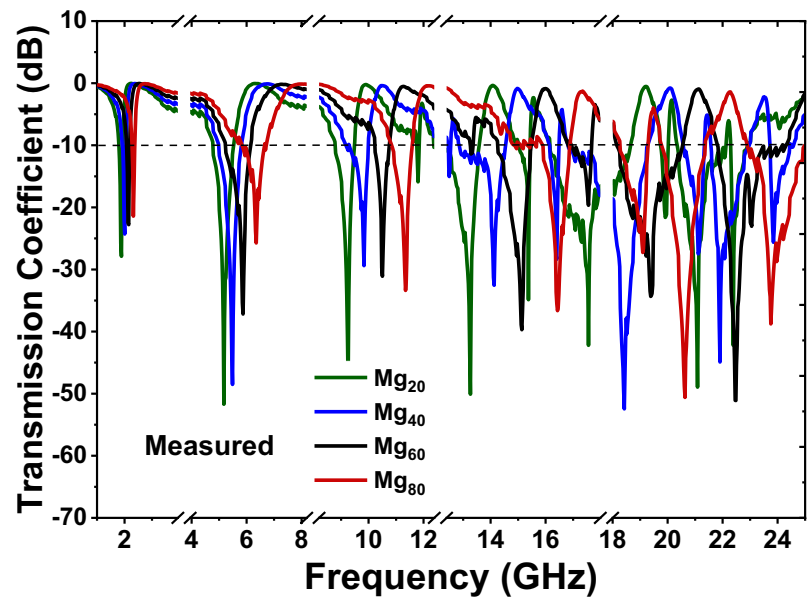

(b)

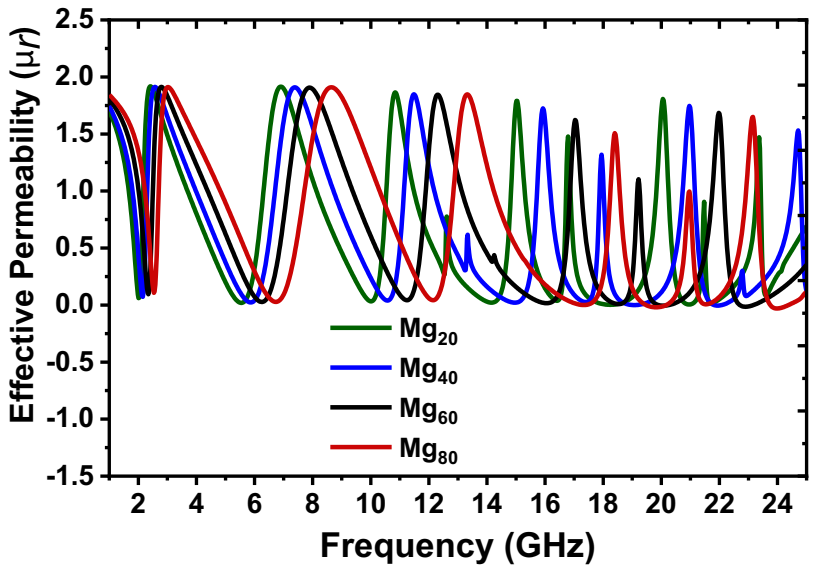

(d)

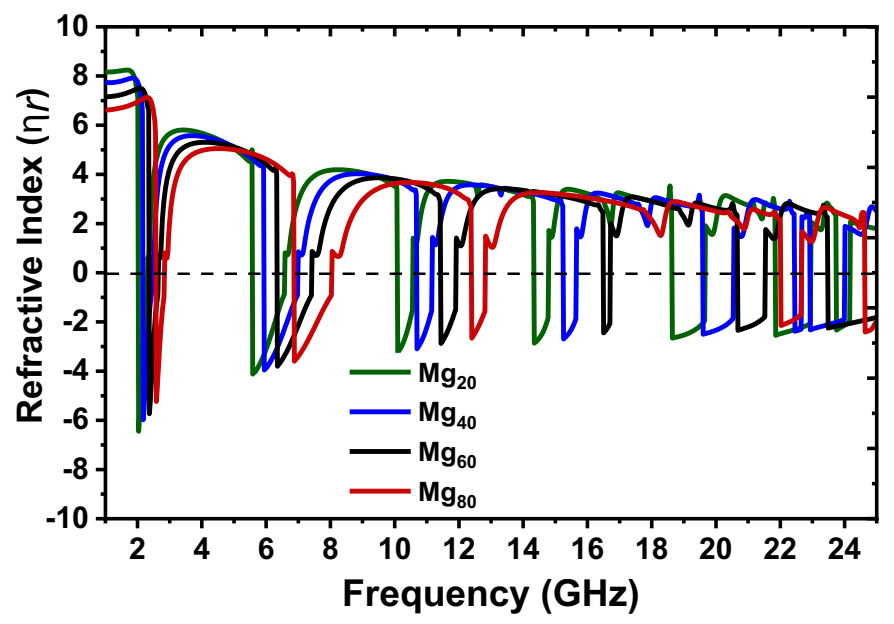

(e)

Figure 11. The amplitude of (a) the simulated transmission coefficient, (b) the measured transmission coefficient, the extracted effective (c) permittivity, (d) permeability, and (e) refractive index for all four concentration of magnesium $\mathrm{Mg}_{20}, \mathrm{Mg}_{40}, \mathrm{Mg}_{60}$, and $\mathrm{Mg}_{80}$.

only five resonances are found with $\mathrm{RO} 4533$, whereas there are seven resonances are investigated with $\mathrm{Mg}_{80}$. All the prepared, flexible substrates, i.e., $\mathrm{Mg}_{20}, \mathrm{Mg}_{40}, \mathrm{Mg}_{60}$, and $\mathrm{Mg}_{80}$ cover S-, C-, X-, Ku-, and $\mathrm{K}-$ band of the microwave regime. Some of the related comparisons among proposed flexible substrates $\mathrm{Mg}_{60}$ and $\mathrm{Mg}_{80}$ with FR4 and RO4533 in terms of substrate type, material type, permittivity, loss tangent, number of resonances, and the band of applications are presented in Table 4. It is seen that in both cases, the proposed materials offer better performances over commercially available materials, which originates due to having tunable dielectric and 


\begin{tabular}{|l|l|l|}
\hline Mg concentration & Effective parameters & Negative frequency region $(\mathbf{G H z})$ \\
\hline \multirow{3}{*}{$\mathrm{Mg}_{20}$} & Permittivity $\left(\varepsilon_{r}\right)$ & $\begin{array}{l}2.02-2.36,5.57-6.74,10.06-10.70,14.29-14.91,16.53-16.73,18.59-19.87,21.18-21.43, \\
21.81-23.28,21.64-25\end{array}$ \\
\cline { 2 - 3 } & Refractive Index $\left(n_{r}\right)$ & $2.02-2.32,5.57-6.58,10.09-10.57,14.33-14.79,18.63-19.66,21.85-22.95,23.74-24.17$ \\
\hline \multirow{3}{*}{$\mathrm{Mg}_{40}$} & Permittivity $\left(\varepsilon_{r}\right)$ & $\begin{array}{l}2.14-2.51,5.91-7.13,10.66-11.30,15.18-15.79,17.63-17.89,19.51-20.77,22.33-22.78, \\
22.87-24.57\end{array}$ \\
\cline { 2 - 3 } & Refractive Index $\left(n_{r}\right)$ & $2.16-2.45,5.93-6.99,10.68-11.17,15.24-15.66,19.58-20.55,22.44-22.66,22.92-24.01$ \\
\hline \multirow{3}{*}{$\mathrm{Mg}_{60}$} & Permittivity $\left(\varepsilon_{r}\right)$ & $2.36-2.73,6.32-7.65,11.38-12.09,16.38-18.92,18.89-19.14,20.55-21.82,23.38-25$ \\
\cline { 2 - 3 } & Refractive Index $\left(n_{r}\right)$ & $2.36-2.65,6.34-7.42,11.42-11.91,16.49-16.71,20.67-21.53,23.47-25$ \\
\hline \multirow{2}{*}{$\mathrm{Mg}_{80}$} & Permittivity $\left(\varepsilon_{r}\right)$ & $2.54-2.95,6.84-8.33,12.31-13.07,17.81-18.30,20.45-20.88,21.86-22.98,24.54-25$ \\
\cline { 2 - 3 } & Refractive Index $\left(n_{r}\right)$ & $2.57-2.84,6.86-8.05,12.38-12.82,22.01-22.66,24.62-25$ \\
\hline
\end{tabular}

Table 3. Negative values of effective parameters among $\mathrm{Mg}_{20}, \mathrm{Mg}_{40}, \mathrm{Mg}_{60}$, and $\mathrm{Mg}_{80}$.

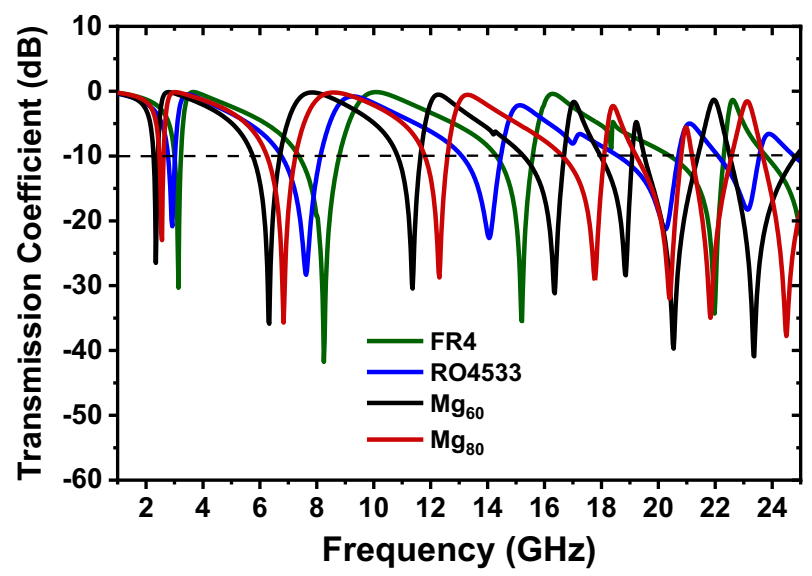

Figure 12. Comparison of transmission coefficients among proposed material with conventional materials.

\begin{tabular}{|l|l|l|l|l|}
\hline Substrate type & FR4 & RO4533 & $\mathbf{M g}_{\mathbf{6 0}}$ & $\mathbf{M g}_{\mathbf{8 0}}$ \\
\hline Material type & Hard & Hard & Flexible & Flexible \\
\hline Permittivity $\left(\varepsilon_{r}\right)$ & 4.30 & 3.45 & 4.30 & 3.40 \\
\hline Loss tangent $\left(\mathrm{T}_{\delta}\right)$ & 0.025 & 0.0025 & 0.006 & 0.008 \\
\hline Number of resonances & 5 & 4 & 7 & 7 \\
\hline Band of application & $\mathrm{S}, \mathrm{C}, \mathrm{Ku}$, and $\mathrm{K}$ & $\mathrm{S}, \mathrm{X}, \mathrm{Ku}$, and K & S, C, X, Ku, and K & S, C, X, Ku, and K \\
\hline
\end{tabular}

Table 4. Comparison of proposed materials with conventional substrate materials.

magnetic properties. The dielectric and magnetic properties are varied for the variations of material percentages, and the percentage of the materials changes the metal and insulator interface of the compounds. And the values of the micro-capacitors array that formed in between the metal-insulator surface also become change, affecting the overall performances. Moreover, the proposed substrates materials are highly flexible, lightweight, and low in cost compared to other commercially available materials.

A summary of the fabricated flexible metamaterials based on sol-gel synthesized $\mathrm{Mg}-\mathrm{Zn}$ ferrite $\left[\mathrm{Mg}_{\mathrm{x}} \mathrm{Zn}_{(1-\mathrm{x})} \mathrm{Fe}_{2} \mathrm{O}_{4}\right]$ composites for all four concentration of magnesium, i.e., $\mathrm{Mg}, \mathrm{Mg}_{40}, \mathrm{Mg}_{60}$, and $\mathrm{Mg}_{80}$, is presented in Table 5 in terms of total dimension, substrate material, operating frequency, resonances, metamaterial type and microwave band of applications. Also, a brief comparison of the proposed metamaterial unit cells in terms of (1) physical dimensions, (2) the type of substrate, (3) the number of resonances obtained, (4) the band of applications, (5) the effective medium ratio (EMR), and (6) the type of metamaterials with some existing literature is presented in Table 6. Here, the EMR is an important factor regarding metamaterials design, which governs the compactness of the designed metamaterial. The EMR is calculated by the following equation.

$$
E M R=\frac{\text { Wavelength of the unit cell }(\lambda)}{\text { Length of the unit cell }(L)}
$$

where $\lambda$ is the electrical wavelength corresponding to the lowest resonance of the transmission parameter $\left(S_{21}\right)$ obtained by the metamaterial unit cell and $\mathrm{L}$ is the maximum physical length of the metamaterial unit cell. The 


\begin{tabular}{|c|c|c|c|c|}
\hline \multirow[b]{2}{*}{ Properties } & \multicolumn{4}{|l|}{ Metamaterial on flexible composites } \\
\hline & With $\mathrm{Mg}_{20}$ & With $\mathrm{Mg}_{40}$ & With $\mathrm{Mg}_{60}$ & With $\mathrm{Mg}_{80}$ \\
\hline Total dimension & $8 \times 6.5 \mathrm{~mm}^{2}$ & $8 \times 6.5 \mathrm{~mm}^{2}$ & $8 \times 6.5 \mathrm{~mm}^{2}$ & $8 \times 6.5 \mathrm{~mm}^{2}$ \\
\hline Electric dimension & $0.054 \lambda \times 0.044 \lambda$ & $0.057 \lambda \times 0.047 \lambda$ & $0.063 \lambda \times 0.051 \lambda$ & $0.068 \lambda \times 0.055 \lambda$ \\
\hline Substrate material & $\begin{array}{l}\text { Magnesium zinc ferrite with a } \\
\text { composition of }\left(\mathrm{Mg}_{0.2} \mathrm{Zn}_{0.8} \mathrm{Fe}_{2} \mathrm{O}_{4}\right)\end{array}$ & $\begin{array}{l}\text { Magnesium zinc ferrite with a } \\
\text { composition of }\left(\mathrm{Mg}_{0.4} \mathrm{Zn}_{0.6} \mathrm{Fe}_{2} \mathrm{O}_{4}\right)\end{array}$ & $\begin{array}{l}\text { Magnesium zinc ferrite with a } \\
\text { composition of }\left(\mathrm{Mg}_{0.6} \mathrm{Zn}_{0.4} \mathrm{Fe}_{2} \mathrm{O}_{4}\right)\end{array}$ & $\begin{array}{l}\text { Magnesium zinc ferrite with a } \\
\text { composition of }\left(\mathrm{Mg}_{0.8} \mathrm{Zn}_{0.2} \mathrm{Fe}_{2} \mathrm{O}_{4}\right)\end{array}$ \\
\hline Operating frequency & $1.93-24.07 \mathrm{GHz}$ & $2.06-23.74 \mathrm{GHz}$ & $2.27-24.86 \mathrm{GHz}$ & $2.46-25^{+} \mathrm{GHz}$ \\
\hline Simulated resonance frequency & $\begin{array}{l}2.03 \mathrm{GHz}, 5.56 \mathrm{GHz}, 10.05 \mathrm{GHz} \text {, } \\
14.27 \mathrm{GHz}, 16.50 \mathrm{GHz}, 18.57 \\
\mathrm{GHz}, 21.16 \mathrm{GHz}, 21.81 \mathrm{GHz} \text {, and } \\
23.61 \mathrm{GHz}\end{array}$ & $\begin{array}{l}2.15 \mathrm{GHz}, 5.92 \mathrm{GHz}, 10.65 \mathrm{GHz} \text {, } \\
15.17 \mathrm{GHz}, 17.58 \mathrm{GHz}, 19.48 \mathrm{GHz} \text {, } \\
\text { and } 22.31 \mathrm{GHz}\end{array}$ & $\begin{array}{l}2.35 \mathrm{GHz}, 6.33 \mathrm{GHz}, 11.34 \mathrm{GHz} \text {, } \\
16.36 \mathrm{GHz}, 18.86 \mathrm{GHz}, 20.54 \mathrm{GHz} \text {, } \\
\text { and } 23.37 \mathrm{GHz} \text {. }\end{array}$ & $\begin{array}{l}\text { 2.56 GHz, } 6.83 \mathrm{GHz}, 12.31 \mathrm{GHz}, \\
17.77 \mathrm{GHz}, 20.40 \mathrm{GHz}, 21.84 \mathrm{GHz} \text {, } \\
\text { and } 24.50 \mathrm{GHz}\end{array}$ \\
\hline Measured resonance frequency & $\begin{array}{l}\text { 1.89 GHz, } 5.18 \mathrm{GHz}, 9.27 \mathrm{GHz}, \\
11.80 \mathrm{GHz}, 13.26 \mathrm{GHz}, 15.38 \mathrm{GHz}, \\
17.56 \mathrm{GHz}, 19.94 \mathrm{GHz}, 21.09 \mathrm{GHz}, \\
\text { and } 22.38 \mathrm{GHz}\end{array}$ & \begin{tabular}{|l|}
$2.01 \mathrm{GHz}, 5.49 \mathrm{GHz}, 9.83 \mathrm{GHz}$, \\
$14.13 \mathrm{GHz}, 16.41 \mathrm{GHz}, 18.43$ \\
$\mathrm{GHz}, 21.14 \mathrm{GHz}, 21.90 \mathrm{GHz}$, and \\
$22.31 \mathrm{GHz}$
\end{tabular} & $\begin{array}{l}2.15 \mathrm{GHz}, 5.87 \mathrm{GHz}, 10.51 \mathrm{GHz} \text {, } \\
15.14 \mathrm{GHz}, 17.58 \mathrm{GHz}, 19.38 \mathrm{GHz} \text {, } \\
\text { and } 22.48 \mathrm{GHz} \text {. }\end{array}$ & $\begin{array}{l}\text { 2.32 GHz, } 6.35 \mathrm{GHz}, 11.35 \mathrm{GHz} \text {, } \\
16.43 \mathrm{GHz}, 19.10 \mathrm{GHz}, 20.63 \mathrm{GHz} \text {, } \\
\text { and } 23.73 \mathrm{GHz}\end{array}$ \\
\hline EMR & 18.47 & 17.44 & 15.96 & 14.65 \\
\hline Applications & S-, C-, X-, Ku-, and K-Band & S-, C-, X-, Ku-, and K-Band & S-, C-, X-, Ku-, and K-Band & S-, C-, X-, Ku-, and K-Band \\
\hline
\end{tabular}

Table 5. Summary of the designed metamaterials on flexible composites.

\begin{tabular}{|l|l|l|l|l|l|l|}
\hline References & Dimensions $\mathbf{( m m})$ & Substrate type & No. of Resonances & Band & EMR & Observations \\
\hline 24 & $25 \times 20$ & Flexible & 7 & S-, C-, X & 3.75 & Larger dimension, narrower bandwidth, and low EMR \\
\hline 25 & $12.5 \times 10$ & Flexible & 2 & X-, Ku & 2.88 & Dual-band only, and very poor EMR value \\
\hline 40 & $10 \times 8$ & Hard & 1 & X & 3.40 & Polarization-dependent, non-flexible, and low EMR \\
\hline 41 & $9 \times 9$ & Hard & 3 & C-, X-, Ku & 5.00 & Non-flexible with poor EMR value \\
\hline 42 & $12 \times 12$ & Hard & 2 & S-, C & 5.55 & Non-flexible, dual-band only with poor EMR value \\
\hline Proposed & $8 \times 6.5$ & Flexible & $7-9$ & S-, C-, X-, Ku-, and K & $14.65-18.47$ & $\begin{array}{l}\text { Highly flexible, lightweight, low electrical dimension, improved } \\
\text { EMR, and polarization-independent }\end{array}$ \\
\hline
\end{tabular}

Table 6. Comparison of proposed metamaterial with some existing literature.

expected value of EMR is $>4$ to achieve the negative permittivity and/or permeability as well as the negative refractive index to perform as a metamaterial. From Table 6, it is observed that Rahman et al. in 2018, have prepared $\mathrm{NiAl} 2 \mathrm{O} 4$ based flexible substrates for metamaterials that offered negative electromagnetic properties with a quite large dimension of $25 \times 20 \mathrm{~mm} 2$ and applicable for S-,C-, and X-bands of microwave regime having seven resonances with very narrow bandwidth at each resonance with an EMR value of 3.75 only $^{24}$. In 2019, a double negative metamaterial on flexible nickel aluminate substrate was proposed by Faruque et al. with a dimension of $12.5 \times 10 \mathrm{~mm} 2$ having dual-band ( $\mathrm{X}$ and $\mathrm{Ku}$ ) only with a very poor EMR value of $2.88^{25}$. A metamaterial having tunneled structure was demonstrated by Ahmed et al. in 2019 with a dimension of $10 \times 8 \mathrm{~mm} 2$, but it is polarization-dependent and has no flexibility as fabricated on conventional hard FR4 substrate. This metamaterial offered only a single microwave band (X) of application, and the value of EMR is 3.40 only ${ }^{40}$. Hasan et al. in 2017, presented a tri-band meta atom on hard Rogers RT 5880 substrate with a reduced dimension of $9 \times 9 \mathrm{~mm} 2$ for having an EMR value of 5 only ${ }^{41}$. Overall, it is seen that the proposed flexible metamaterial is electrically compact and possessed with improved EMR value, wide bandwidth, and SNG properties. Thus, the proposed metamaterials with new flexible microwave substrates overcome all the previous significant drawbacks like low EMR, narrow bandwidth, larger size, etc. and it is suitably applicable for S-, C-, X-, Ku-, and K-band of microwave regime as well as within flexible microwave technology.

\section{Conclusion}

In this study, the authors have been developed SNG metamaterial upon sol-gel synthesized $\mathrm{Mg}_{\mathrm{x}} \mathrm{Zn}_{(1-\mathrm{x})} \mathrm{Fe}_{2} \mathrm{O}_{4}$ based flexible microwave composites having four different compound ratios termed $\mathrm{Mg}_{20}, \mathrm{Mg}_{40}, \mathrm{Mg}_{60}$, and $\mathrm{Mg}_{80}$. Due to having different compositional ratios, they possess various/tunable structural and microwave properties. The synthesized composites have average crystallite sizes of the spinel from 20 to $24 \mathrm{~nm}$, and they exhibit high dielectric permittivity values that varied from 6.01 to 3.28 and loss tangents from 0.002 and 0.008 , for $\mathrm{Mg}_{20}$ to $\mathrm{Mg}_{80}$, respectively. Moreover, the fabricated metamaterials on flexible composites offer a wide band of operating frequencies with single negative characteristics at nine different resonances by $\mathrm{Mg}_{20}$ and at seven different resonances by the rest of all $\left(\mathrm{Mg}_{40}, \mathrm{Mg}_{60}\right.$, and $\left.\mathrm{Mg}_{80}\right)$ that ranges from S- to K-band of microwave regime. A very good agreement is found among simulation and measured values with improved EMR values that are calculated from 14.65 to 18.47 . The advantages of the prepared composites are they are cost-effective, highly flexible, lightweight, and applicable in the case of wearable devices, and also have shown better performances comparing with conventional FR4 and Rogers RO4533 substrates. Thus, the overall investigations confirm that the proposed flexible metamaterials are the prominent candidate for the S-, C-, X-, Ku- and K-bands of the microwave frequency range as well as flexible microwave technologies. 
Received: 7 January 2021; Accepted: 23 March 2021

Published online: 07 April 2021

\section{References}

1. Suguna, S., Shankar, S., Jaganathan, S. K. \& Manikandan, A. Novel synthesis of spinel $\mathrm{Mn}_{\mathrm{x}} \mathrm{Co}_{1-\mathrm{x}} \mathrm{Al}_{2} \mathrm{O}_{4}(\mathrm{x}=0.0$ to 1.0$)$ nanocatalysts: effect of $\mathrm{Mn}^{2+}$ doping on structural, morphological, and opto-magnetic properties. J. Supercond. Novel Magn.etism 30, 691-699 (2017).

2. Loharkar, P. K., Ingle, A. \& Jhavar, S. Parametric review of microwave-based materials processing and its applications. J. Mater. Res. Technol. 8, 3306-3326 (2019).

3. Hazra, S. \& Ghosh, N. Preparation of nanoferrites and their applications. J. Nanosci. Nanotechnol. 14, 1983-2000 (2014).

4. Pacakova, B., Kubickova, S., Reznickova, A., Niznansky, D., \& Vejpravova, J. Spinel ferrite nanoparticles: correlation of structure and magnetism. In Magnetic Spinels-Synthesis, Properties and Applications, 4-6 (2017).

5. Manikandan, A., Durka, M., Seevakan, K. \& Antony, S. A. A novel one-pot combustion synthesis and opto-magnetic properties of magnetically separable spinel $\mathrm{Mn}_{\mathrm{x}} \mathrm{Mg}_{1-\mathrm{x}} \mathrm{Fe}_{2} \mathrm{O}_{4}(0.0 \leq \mathrm{x} \leq 0.5)$ nanophotocatalysts. J. Supercond. Novel Magn. 28, 1405-1416 (2015).

6. Algarou, N. et al. Magnetic and microwave properties of $\mathrm{SrFe}_{12} \mathrm{O}_{19} / \mathrm{MCe}_{0.04} \mathrm{Fe}_{1.96} \mathrm{O}_{4}(\mathrm{M}=\mathrm{Cu}, \mathrm{Ni}, \mathrm{Mn}, \mathrm{Co}$ and $\mathrm{Zn})$ hard/soft nanocomposites. J. Mater. Res. Technol. 9, 5858-5870 (2020).

7. Song, F., Shen, X., Liu, M. \& Xiang, J. Preparation and magnetic properties of $\mathrm{SrFe}_{12} \mathrm{O}_{19} / \mathrm{Ni}_{0.5} \mathrm{Zn}_{0.5} \mathrm{Fe}_{2} \mathrm{O}_{4}$ nanocomposite ferrite microfibers via sol-gel process. Mater. Chem. Phys. 126, 791-796 (2011).

8. Tatarchuk, T. et al. Synthesis, morphology, crystallite size and adsorption properties of nanostructured $\mathrm{Mg}-\mathrm{Zn}$ ferrites with enhanced porous structure. J. Alloys Compd. 819, 152945 (2020).

9. Li, K. \& Rizzo, P. Experimental parametric analysis of an energy harvester based on highly nonlinear solitary waves. J. Intell. Mater. Syst. Struct. 28, 772-781 (2017).

10. Bowen, P. T., Baron, A. \& Smith, D. R. Theory of patch-antenna metamaterial perfect absorbers. Phys. Rev. A 93, 063849 (2016).

11. Saif, H., Islam, M. T., Almutairi, A. F. \& Iqbal, F. M. R. Wide bandwidth angle-and polarization-insensitive symmetric metamaterial absorber for X and Ku band applications. Sci. Rep. 10, 1-9 (2020).

12. Jin, J. Y., Lin, X. Q. \& Xue, Q. A novel dual-band bandpass E-plane filter using compact resonators. IEEE Microw. Wirel. Compon. Lett. 26, 484-486 (2016).

13. Vrba, D., Rodrigues, D. \& Stauffer, P. R. Metamaterial antenna arrays for improved uniformity of microwave hyperthermia treatments. Prog. Electromagn. Res. 156, 1-12 (2016).

14. Miniaci, M., Krushynska, A., Bosia, F. \& Pugno, N. M. Large scale mechanical metamaterials as seismic shields. New J. Phys. 18, 083041 (2016)

15. Radoń, A., Łukowiec, D. \& Włodarczyk, P. Microwave absorption by dextrin-magnetite nanocomposite in frequencies below 2.5 GHz: role of magnetite content, shape and temperature on magneto-dielectric properties. Mater. Des. 193, 108860 (2020).

16. Ahasanul, H., Islam, M. T., Almutairi, A. F., Chowdhury, M. E. \& Samsuzzaman, M. SNG and DNG meta-absorber with fractional absorption band for sensing application. Sci. Rep. 10, 1-7 (2020).

17. Liyakath, R. A., Takshi, A. \& Mumcu, G. Multilayer stretchable conductors on polymer substrates for conformal and reconfigurable antennas. IEEE Antennas Wirel. Propag. Lett. 12, 603-606 (2013).

18. Hayes, G. J., So, J.-H., Qusba, A., Dickey, M. D. \& Lazzi, G. Flexible liquid metal alloy (EGaIn) microstrip patch antenna. IEEE Trans. Antennas Propag. 60, 2151-2156 (2012).

19. Rahman, A., Islam, M. T., Samsuzzaman, M., Singh, M. J. \& Akhtaruzzaman, M. Preparation and characterization of flexible substrate material from phenyl-thiophene-2-carbaldehyde compound. Materials 9, 358 (2016).

20. Hou, S. et al. Excellent Terahertz shielding performance of ultrathin flexible Cu/graphene nanolayered composites with high stability. J. Mater. Sci. Technol. 52, 136-144 (2020).

21. Rahman, A., Islam, M. T., Singh, M. J. \& Misran, N. Sol-gel synthesis of transition-metal doped ferrite compounds with potential flexible, dielectric and electromagnetic properties. Rsc Adv. 6, 84562-84572 (2016).

22. Al Yaqoob, K., Bououdina, M., Akhter, M., Al Najar, B. \& Vijaya, J. J. Selectivity and efficient $\mathrm{Pb}$ and Cd ions removal by magnetic $\mathrm{MFe}_{2} \mathrm{O}_{4}(\mathrm{M}=\mathrm{Co}, \mathrm{Ni}, \mathrm{Cu}$ and $\mathrm{Zn})$ nanoparticles. Mater. Chem. Phys. 232, 254-264 (2019).

23. Jiang, Q. et al. Design and X-band electromagnetic response of single negative metacomposite containing periodic curved Cobased ferromagnetic microwires. J. Mater. Res. Technol. 9, 4593-4603 (2020).

24. Rahman, M. A., Ahamed, E., Faruque, M. R. I. \& Islam, M. T. Preparation of $\mathrm{NiAl}_{2} \mathrm{O}_{4}$-based flexible substrates for metamaterials with negative dielectric properties. Sci. Rep. 8, 1-13 (2018).

25. Faruque, M. R. I., Ahamed, E., Rahman, M. A. \& Islam, M. T. Flexible nickel aluminate $\left(\mathrm{NiAl}_{2} \mathrm{O}_{4}\right)$ based dual-band double negative metamaterial for microwave applications. Results Phys. 14, 102524 (2019).

26. Nordin, N. et al. Characterisation of sol-gel method synthesised MgZnFe2O4 nanoparticles and its cytotoxic effects on breast cancer cell line, MDA MB-231 in vitro. IET Nanobiotechnol. 11, 343-348 (2016).

27. Bahramiabarghouei, H. et al. Flexible 16 antenna array for microwave breast cancer detection. IEEE Trans. Biomed. Eng. 62, 2516-2525 (2015).

28. Yang, R. et al. Effect of $\mathrm{Mg}$ doping on magnetic induction heating of $\mathrm{Zn}-\mathrm{Co}$ ferrite nanoparticles. J. Alloys Compd. 851, 56907 (2021).

29. Williams, C., Chrisey, D., Lubitz, P., Grabowski, K. \& Cotell, C. The magnetic and structural properties of pulsed laser deposited epitaxial MnZn-ferrite films. J. Appl. Phys. 75, 1676-1680 (1994).

30. Huang, X. et al. Tunable electromagnetic properties and enhanced microwave absorption ability of flaky graphite/cobalt zinc ferrite composites. J. Alloys Compd. 662, 409-414 (2016).

31. Huang, X., Zhang, J., Xiao, S. \& Chen, G. The cobalt zinc spinel ferrite nanofiber: lightweight and efficient microwave absorber. J. Am. Ceram. Soc. 97, 1363-1366 (2014).

32. Naidu, V., Pragasam, D. J., Jeeva, R. K., Nithya, N. \& Maraikkayar, S. S. M. A. Structural studies of nano dielectric substrate material for millimeter wave antenna. Int. J. Appl. Eng. Res. 10, 2015 (2015).

33. Dippong, T., Deac, I. G., Cadar, O., Levei, E. A. \& Petean, I. Impact of $\mathrm{Cu}^{2+}$ substitution by $\mathrm{Co}^{2+}$ on the structural and magnetic properties of $\mathrm{CuFe}_{2} \mathrm{O}_{4}$ synthesized by sol-gel route. Mater. Charact. 163, 110248 (2020).

34. Rahman, A., Islam, M. T., Zulfakar, M. S. \& Abdullah, H. Synthesis and characterization of gahnite-based microwave dielectric ceramics (MDC) for microstrip antennas prepared by a sol-gel method. J. Sol-Gel Sci. Technol. 74, 557-565 (2015).

35. Shi, S. et al. Electrospinning fabrication of flexible $\mathrm{Fe}_{3} \mathrm{O}_{4}$ fibers by sol-gel method with high saturation magnetization for heavy metal adsorption. Mater. Des. 186, 108298 (2020).

36. Cui, T., Smith, D. \& Liu, R. Metamaterials: Theory, Design, and Applications Vol. 13 (Springer, New York, 2010).

37. Islam, M. R., Samsuzzaman, M., Misran, N., Beng, G. K. \& Islam, M. T. A tri-band left-handed meta-atom enabled designed with high effective medium ratio for microwave based applications. Results Phys. 17, 103032 (2020).

38. Liu, X. et al. Tunable metamaterial absorber based on resonant strontium titanate artificial atoms. J. Mater. Sci. Technol. 62, 249-253 (2020).

39. Choi, M., Choe, J.-H., Kang, B. \& Choi, C.-G. A flexible metamaterial with negative refractive index at visible wavelength. Curr. Appl. Phys. 13, 1723-1727 (2013). 
40. Ahamed, E., Faruque, M. R. I., Mansor, M. F. B. \& Islam, M. T. Polarization-dependent tunneled metamaterial structure with enhanced fields properties for X-band application. Results Phys. 15, 102530 (2019).

41. Hasan, M. M., Faruque, M. R. I. \& Islam, M. T. Multiband left handed biaxial meta atom at microwave frequency. Mater. Res. Express 4, 035015 (2017).

42. Hossain, M. I., Faruque, M. R. I., Islam, M. T. \& Ullah, M. H. A new wide-band double-negative metamaterial for C-and S-band applications. Materials 8, 57-71 (2015).

43. Misran, N., Yusop, S. H., Islam, M. T. \& Ismail, M. Y. Analysis of parameterization substrate thickness and permittivity for concentric split ring square reflectarray element. J. Kejuruter. 23, 11-16 (2012).

44. Ullah, M. H. \& Islam, M. A new metasurface reflective structure for simultaneous enhancement of antenna bandwidth and gain. Smart Mater. Struct. 23, 085015 (2014).

45. Cheng, C. et al. Tunable and weakly negative permittivity in carbon/silicon nitride composites with different carbonizing temperatures. Carbon 125, 103-112 (2017).

46. Wang, X. A. et al. Tunable electromagnetic properties in $\mathrm{Co} / \mathrm{Al}_{2} \mathrm{O}_{3}$ cermets prepared by wet chemical method. J. Am. Ceram. Soc. 97, 3223-3229 (2014).

47. Kumar, N. S., Suvarna, R. P. \& Naidu, K. C. B. Negative dielectric behavior in tetragonal $\mathrm{La}_{0.8} \mathrm{Co}_{0.2-\mathrm{x}} \mathrm{Eu}_{\mathrm{x}} \mathrm{TiO}_{3}(\mathrm{x}=0.01-0.04)$ nanorods. Mater. Charact. 166, 110425 (2020).

48. Wei, Y.-L., Yang, Q.-S., Ma, L.-H., Tao, R. \& Shang, J.-J. Design and analysis of 2D/3D negative hydration expansion Metamaterial driven by hydrogel. Mater. Des. 196, 109084 (2020).

49. Zhang, Y. et al. Flexible and wearable sensor based on graphene nanocomposite hydrogels. Smart Mater. Struct. 29, 075027 (2020).

50. Rahman, S. et al. Structural and magnetic properties of $\mathrm{ZnMg}$-ferrite nanoparticles prepared using the co-precipitation method. Ceram. Int. 39, 5235-5239 (2013).

51. Somvanshi, S. B., Khedkar, M. V., Kharat, P. B. \& Jadhav, K. Influential diamagnetic magnesium $\left(\mathrm{Mg}^{2+}\right)$ ion substitution in nanospinel zinc ferrite ( $\mathrm{ZnFe} 2 \mathrm{O} 4)$ : thermal, structural, spectral, optical and physisorption analysis. Ceram. Int. 46, 8640-8650 (2020).

52. Denton, A. R. \& Ashcroft, N. W. Vegard's law. Phys. Rev. A 43, 3161 (1991).

53. Koops, C. On the dispersion of resistivity and dielectric constant of some semiconductors at audiofrequencies. Phys. Rev. 83, 121 (1951)

54. Wagner, K. W. Zur theorie der unvollkommenen dielektrika. Ann. Phys. 345, 817-855 (1913).

55. Nicolson, A. \& Ross, G. Measurement of the intrinsic properties of materials by time-domain techniques. IEEE Trans. Instrum. Meas. 19, 377-382 (1970).

\section{Acknowledgment}

This work is supported by the Ministry of Higher Education, Malaysia, the Fundamental Research Grant Schemes (FRGS), having the research Grant Number of FRGS/1/2018/TK04/UKM/01/1. This work was also supported by Grant NPRP12S-0227-190164 from the Qatar National Research Fund, a member of Qatar Foundation, Doha, Qatar, and the claims made herein are solely the responsibility of the authors.

\section{Author contributions}

M.A.R. and M.S. contributed significantly to the planning, analysis of the findings, preparation, and paper writing. M.A.R. and M.T.I. carried out the result analysis then reviewed the desired results and M.T.I. oversaw the entire investigation and financing. M.S.J.S. and M.S. has reviewed the text, concept optimization, characterization, empirical findings, and critical recommendations. M.S. and M.E.H.C. has updated the article judgmentally and reviewed useful recommendations for relevant intellectual material. All authors have read the manuscript and agreed to publish it.

\section{Competing interests}

The authors declare no competing interests.

\section{Additional information}

Correspondence and requests for materials should be addressed to M.A.R., M.T.I. or M.E.H.C.

Reprints and permissions information is available at www.nature.com/reprints.

Publisher's note Springer Nature remains neutral with regard to jurisdictional claims in published maps and institutional affiliations.

(c) (i) Open Access This article is licensed under a Creative Commons Attribution 4.0 International License, which permits use, sharing, adaptation, distribution and reproduction in any medium or format, as long as you give appropriate credit to the original author(s) and the source, provide a link to the Creative Commons licence, and indicate if changes were made. The images or other third party material in this article are included in the article's Creative Commons licence, unless indicated otherwise in a credit line to the material. If material is not included in the article's Creative Commons licence and your intended use is not permitted by statutory regulation or exceeds the permitted use, you will need to obtain permission directly from the copyright holder. To view a copy of this licence, visit http://creativecommons.org/licenses/by/4.0/.

(C) The Author(s) 2021 